\title{
Inflation Targeting and Exchange Rate Regimes in Emerging Markets
}




\title{
WP/15/228
}

\section{IMF Working Paper}

\section{Inflation Targeting and Exchange Rate Regimes in Emerging Markets}

\author{
by Christian Ebeke and Armand Fouejieu Azangue
}

IMF Working Papers describe research in progress by the author(s) and are published to elicit comments and to encourage debate. The views expressed in IMF Working Papers are those of the author(s) and do not necessarily represent the views of the IMF, its Executive Board, or IMF management.
I $\mathrm{N}$
R N A T I O N A L
$M O N E T A R Y$
F U N D 


\title{
IMF Working Paper
}

European Department

\section{Inflation Targeting and Exchange Rate Regimes in Emerging Markets ${ }^{1}$ \\ Prepared by Christian Ebeke and Armand Fouejieu Azangue}

Authorized for distribution by Daria Zakharova

October 2015

\section{IMF Working Papers describe research in progress by the author(s) and are published} to elicit comments and to encourage debate. The views expressed in IMF Working Papers are those of the author(s) and do not necessarily represent the views of the IMF, its Executive Board, or IMF management.

\begin{abstract}
This paper investigates the effects of the adoption of inflation targeting (IT) on the choice of exchange rate regime in emerging markets (EMs), conditional on certain macroeconomic conditions. Using a large sample of EMs and after controlling for the selection bias associated with the adoption of IT, we find that IT countries on average have a relatively more flexible exchange rate regime than other EMs. However, the flexibility of the exchange rate regime shows strong heterogeneity among IT countries depending on their degree of openness and exposure to FX risks. Moreover, we find that the marginal effect of IT adoption on the exchange rate flexibility increases with the duration of the IT regime in place, and with the propensity scores to adopt it.
\end{abstract}

JEL Classification Numbers: E5; C1; F3; F6

Keywords: Inflation targeting; Exchange rate regime; Non-linearities

Author's E-Mail Address: cebeke@imf.org; afouejieu@imf.org

\footnotetext{
${ }^{1}$ We are indebted to Daria Zakharova, Ken Kang, Shekhar Aiyar, Francisco Vazquez, Andrew Berg, and Selim Elekdag for the insightful comments provided on an earlier draft of this paper. We also thank participants at the IMF EUR Surveillance Meetings and IMF Workshop on Monetary Policy in Low and Middle Income Countries for fruitful discussions on several aspects of the paper.
} 


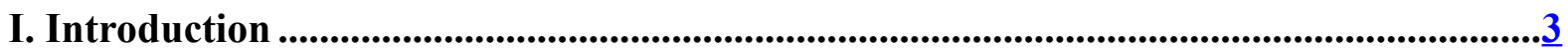

II. Data and Preliminary Discussion .........................................................................................

A. Financial Instability ……………………………………………………………………………

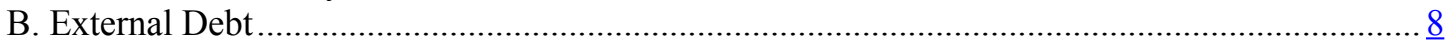

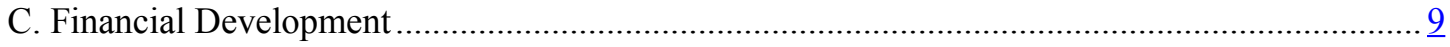

D. Inflation and Exchange Rate Pass-Through .........................................................................

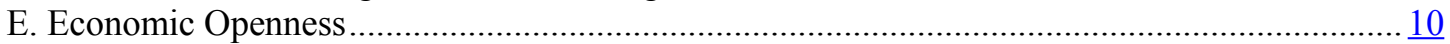

III. Empirical Framework: Ordered Probit/Logit Models ........................................................10

A. The Model …………………………………………………………………10

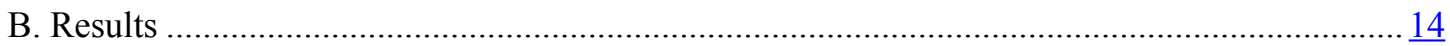

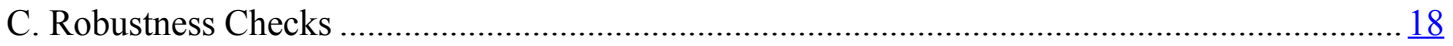

IV. Propensity Score Matching Estimates .................................................................................21

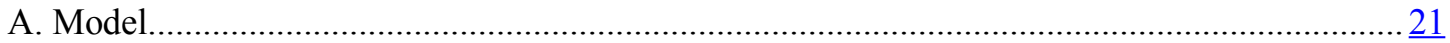

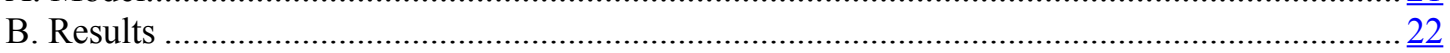

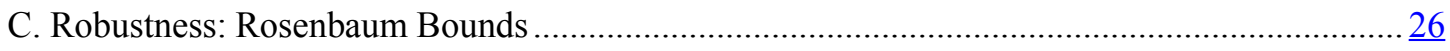

V. Conclusion.............................................................................................................................

Appendix ..........................................................................................................................................

Tables

1. Random Effects Ordered Probit Estimates ...................................................................

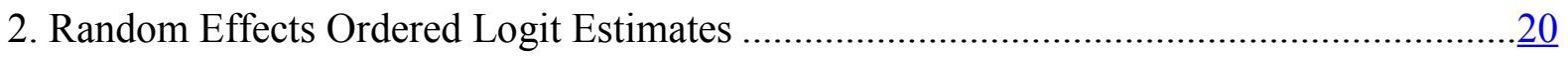

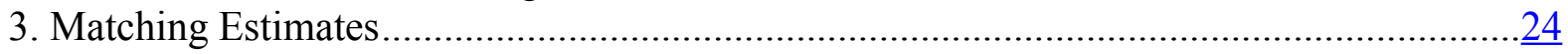

\section{Figure}

1. Adoption of Inflation Targeting, ERR, and Macroeconomic Conditions..............................

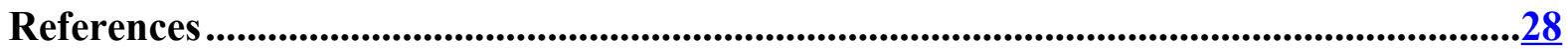

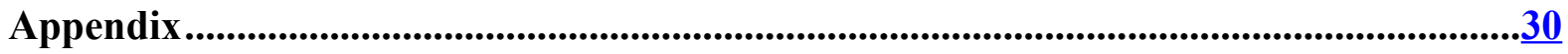

Appendix Tables

1. De Facto Exchange Rate Regime Classification ……….............................................

2. Sample

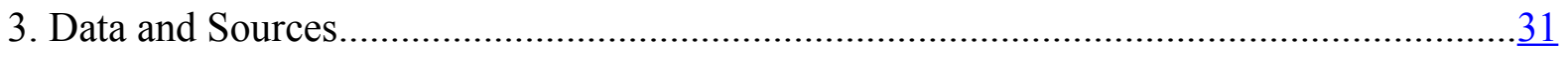

4. Robustness-Random Effects Ordered Probit Estimates (Controlling for Crisis

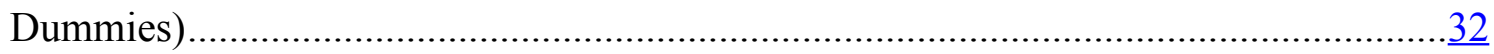

5. Robustness-Random Effects Ordered Probit Estimates (Controlling for Central Bank

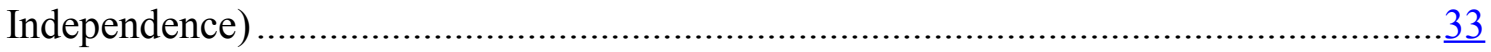

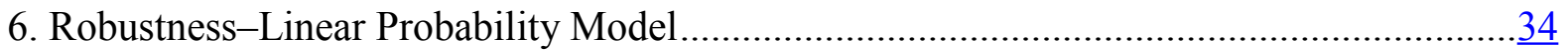

7. Probit Model of the Matching Estimates …………….................................................... 


\section{INTRODUCTION}

The inflation targeting (IT) regime is an institutional arrangement in which the mandate of the central bank is to target a defined medium-term inflation rate which is compatible with macroeconomic stability. The main policy instrument generally used in this set-up is the official policy interest rate, which is adjusted whenever the projected inflation rate over the forecast horizon significantly deviates from the central bank announced inflation target.

Several conditions are generally attached to the adoption and the implementation of an effective and credible IT regime. First, the main mandate of the central bank is to maintain the inflation rate close to the official target. Second, pressures that could prevent the central bank from focusing on this main objective, such as government budget financing or exchange rate policies must be limited and should not conflict with the central bank's main mandate. The main implication of IT is that price stability has priority over other goals such as exchange rate stabilization. However, in practice, and we will confirm it empirically, many IT central banks are concerned to some degree about exchange rate fluctuations.

This paper examines to what extent central banks in emerging markets (EMs) which have adopted IT tend to face a conflict of objectives when certain circumstances arise. In principle, IT countries should exhibit a relatively flexible exchange rate regime arrangement given that the main goal of monetary policy is price stability. This paper aims to demonstrate that under certain specific macroeconomic conditions, the positive association between inflation targeting and exchange rate flexibility disappears. This suggests that IT central banks are tempted to manage the exchange rate more closely under certain conditions, for example under limited degree of economy's openness (trade and financial), limited financial development, or if financial stability is a matter of concern.

While the traditional literature on the determinants of exchange rate regimes (ERRs) has mainly focused on the impacts of macroeconomic and structural (institutions, country size, etc.) variables on the exchange rate policy (Klein and Shambaugh, 2010; Rose, 2011), little is known about the interaction between the IT regime and the ERR. In the same vein, the macroeconomic literature on the effect of IT adoption has examined the effects on various outcomes such as inflation, fiscal performance, and growth (Vega and Winkelried, 2005; Mishkin and Schmidt-Hebbel 2007; Gonçalves and Salles, 2008; Lin and Ye, 2009; Abo-Zaid and Tuzemen, 2012; Minea and Tapsoba, 2014, among others); but has largely neglected the existence of possible "fear of floating" cases within this group of countries. This paper shows that changes in the macroeconomic and financial environment determine this outcome. One of the very few papers which is closely related to ours is Lin (2010) which investigated empirically the link between IT adoption and flexibility of the nominal exchange rate. While Lin's paper does not look at possible non-linear or conditional effects, it shows that the adoption of IT has led countries to exhibit a higher volatility of the nominal exchange rate.

Our paper expands and complements this work on a number of fronts. First, we are interested in the characteristics of the macroeconomic environment which make IT countries more prone to deviate from the flexibility commitment they share on average. To answer this question in this paper, an empirical framework is proposed which allows testing various 
conditional variables while addressing the self-selection bias associated with the adoption of IT. Second, the paper makes use of the de facto classification of the exchange rate regimes instead of the computed standard deviation of the nominal exchange rate. Ordered models of limited dependent variables, as well as average treatment effects from propensity score matching estimators are used to identify the effects of IT adoption on ERR.

This paper also follows the literature which has demonstrated the extent of "disagreement" between countries' de jure and de facto regimes, and between various existing datasets on exchange rate regime classifications. Rose (2011) documents the stylized facts by showing that existing datasets exhibit a significant level of "disagreement" (the departure of de facto exchange rate regime from the de jure classification) when classifying countries' exchange rate regimes. More recently, Eichengreen and Razo-Garcia (2013) showed empirically that "disagreements" in flexibility between various de facto regimes are not uncommon, and they are not random. They are most prevalent in middle-income countries (emerging markets) and low-income (developing) countries as opposed to advanced economies. They are also most prevalent in countries with well-developed financial markets, low reserves, and open capital accounts. Our paper looks at similar issues but from a different angle. It starts by demonstrating that IT countries exhibit more flexible de facto ERR than others (see a similar exercise conducted by Lin, 2010). This is not surprising. Then, the paper juxtaposes the degree of flexibility among IT countries against the prevailing macroeconomic environment. It shows that the "disagreement" increases following shifts in macroeconomic conditions. These results highlight the difficulty faced by some EMs performing under an IT arrangement in sticking to their flexible exchange rate commitment.

There are several channels or possible explanations of why some IT countries would significantly target or manage the nominal exchange rate even if on average, their exchange rate is more flexible than in other countries. Let's start with countries highly dependent on imports of goods and services from abroad. Assuming that the exchange rate pass-through is positively correlated with the degree of trade openness, sharp fluctuations of the country's bilateral exchange rate with key trading partners could have important macroeconomic implications for the real economy. Some central banks might therefore find foreign exchange (FX) intervention a useful tool in controlling inflation and reaching their inflation objective. However, a forward-looking central bank will not necessarily react too quickly to movements in the exchange rate as long as the inflation forecast remains within the tolerated range. The question then boils down to a trade-off between trying to stabilize the exchange rate and the near-term inflation and anchoring inflation expectations by targeting a mediumterm inflation level.

The "fear of floating" can also be understood in the context of financial stability objectives in EMs. Past episodes of financial, banking, sovereign, and currency crises in EMs could explain why some IT countries are cautious about exchange rate flexibility. Consider, for example, a country in which the banking system is dominated by subsidiaries of foreign banks or where mortgage loans are large and issued in foreign currencies. Alternatively, consider a country exhibiting a higher share of public debt denominated in foreign currency or a large share of foreign investors in the domestic debt market. There is an obvious rationale for why these IT countries could exhibit less exchange-rate flexibility than others. The reason is that in these economies even a moderate unexpected (unhedged) shock to the 
nominal exchange rate could potentially worsen banks' balance sheets (higher default on foreign currency denominated mortgages) and public sector debt sustainability could become a concern. This poses a fundamental question of whether financial stability should be an explicit objective of the central banks in the context of IT. An argument can be made that policymakers in an IT regime should worry about financial stability if it poses risks to achieving the inflation target. In this context, a related issue is the ability of central banks in IT countries to achieve financial stability objectives. Relying solely on controlling the policy interest rate may not be sufficient to both stabilize inflation and the financial system. The policy instruments available to IT central banks would have to be expanded to meet financial stability objectives (e.g., by strengthening macroprudential tools), raising the issue of the multiplicity of both objectives and instruments and therefore an evident credibility problem that the adoption of IT regimes tried to address in the first place.

These examples highlight the tensions and challenges faced by modern central banks in EM countries. With increased global trade and financial integration of EMs, the issue of the optimal architecture for monetary policy, taking into account spillovers from global partners, is at the forefront of the policy and academic debate. The challenges associated with globalization have led central banks in EMs to pursue a wide range of policy objectives in addition to their inflation mandate, in some cases putting the credibility of their commitment to targeting inflation into question.

The paper is organized as follows. Section 2 presents the data and discusses some stylized facts. In section 3, we present the baseline empirical analysis and discuss preliminary results. We use ordered probit and logit estimators applied to panel data to investigate the existence of non-linearities in the effect of the IT adoption on the degree of exchange rate flexibility. Section 4 then makes use of propensity score matching estimators as a way to tackle the selfselection bias surrounding the adoption of the IT (as in Lin, 2010). In line with recent literature, the quality of the propensity score estimates is gauged by computing Rosenbaum bounds, a methodology aimed at measuring the extent of hidden biases in estimates. The results show that our matching estimates are relatively less sensitive to unobserved heterogeneity and to hidden bias. Section 5 concludes.

\section{Data And Preliminary Discussion}

Our analysis relies on the de facto classification of countries' ERR as shown in Appendix Table 1. The basic classification encompasses several exchange rate arrangements classified into six categories coded from 1 to 6 , describing the most fixed (hard peg) and the most flexible regimes respectively. We drop the two last categories (5 and 6), keeping "freely floating" as the most flexible ERR. ${ }^{2}$ The analysis is based on a sample of 36 EMs, including 16 IT countries, selected on the basis of data availability (see Appendix Table 2). We use annual data for the period 1985-2010. Table 3 in the Appendix provides detailed information regarding the sources of the data and their proper definitions.

\footnotetext{
${ }^{2}$ Note that the $5^{\text {th }}$ category mostly captures hyperinflationary periods, and the $6^{\text {th }}$ category includes countries or periods that cannot be classified due to lack of data availability.
} 
The purpose of the study is to assess the extent to which, above and beyond its common determinants, the monetary policy framework can affect the choice of an exchange rate regime. We are particularly interested in investigating whether the adoption of the inflation targeting strategy increases the probability of relying more on a floating exchange rate regime. As argued above, for the inflation targeting strategy to be effective, and to improve the central bank's credibility regarding its inflation objective, IT countries are expected to have a flexible ERR (implying no, or very limited, interventions on the FX market). Figure 1 shows that on average, the correlation between IT and the flexibility of the de facto exchange rate regime is positive (first panel, left chart), suggesting a more flexible exchange rate regime in the sample of IT countries, compared to their non-IT counterparts.

When focusing on the sample of IT countries, the data also show that the ERR moves significantly toward more flexibility after the adoption of IT (see the "Baseline" plot in Figure 1). This suggests that full ERR flexibility as a necessary precondition to the implementation of the IT monetary policy strategy does not hold in EMs, because instead they enter more floating regimes later, after the announcement of IT adoption. We argue that the extent to which the adoption of inflation targeting is associated with an increase in the flexibility of the ERR can be affected by the macroeconomic environment. Some of those macroeconomic factors can favor a move toward more flexibility, while others are likely to increase the "fear of floating" in inflation targeting countries. Below, we discuss these macroeconomics conditions, which are mainly related to financial stability, inflation stabilization, and economic openness. 
Figure 1. Adoption of Inflation Targeting, ERR, and Macroeconomic Conditions
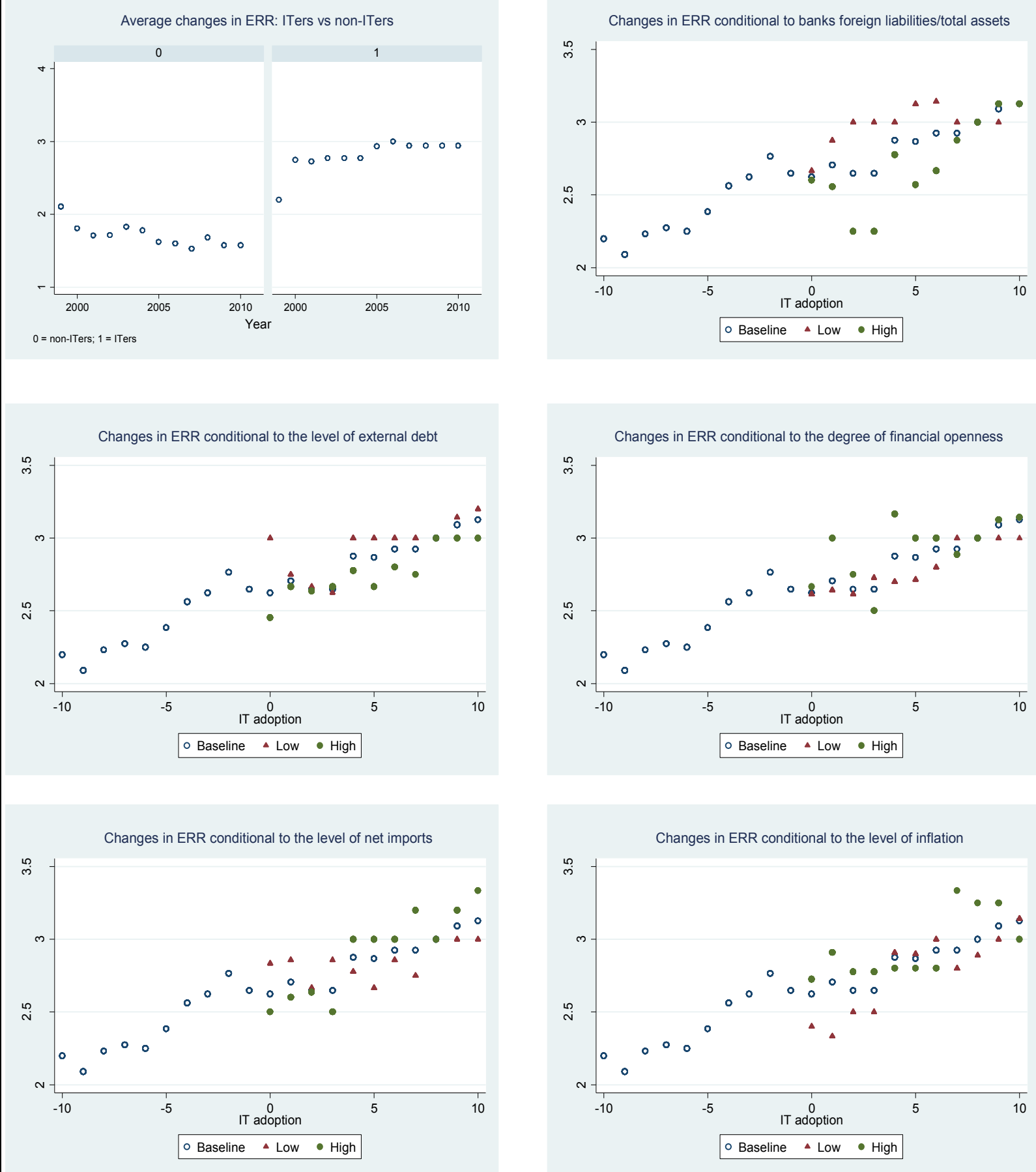

Note: For each macroeconomic variables "Low" repesents inflation targeting observations below the median, while "High" captures inflation targeting observations above the median. 0 on the $x$-axis indicates the year of inflation targeting adoption.

Sources: Authors' calculations based on Reinhart and Rogoff (2010); IMF World Economic Outlook; Roger (2009); Lane and Milesi-Ferretti (2011). 


\section{A. Financial Instability}

Safeguarding the domestic financial system from external shocks is one of the main reasons for emerging countries' interventions on the FX markets. Higher financial system vulnerability to external shocks increases the likelihood of central bank FX interventions and reduces the flexibility of the ERR. For the purpose of our empirical investigation, the following factors are considered:

- $\quad$ Foreign assets to total assets. The ratio of foreign assets to total assets aims to capture the banking sector's exposure to adverse shocks from international financial markets. The higher the share of the domestic banks' total assets invested abroad, the higher the vulnerability of the domestic financial system to negative international financial shocks. ${ }^{3}$ More generally, an increase in foreign assets (capital outflows) is usually perceived as potentially destabilizing for the financial sector, especially in emerging economies.

- $\quad$ Foreign liabilities to total assets. The ratio of banking sector foreign liabilities to total assets is also an important variable to consider, since it may capture another type of external risk related to the banking sector external indebtedness as a share of total bank assets. For the particular case of emerging markets, a larger share of banks' foreign liabilities is denominated in foreign currency, posing risks to the domestic financial system in case of large exchange rate shocks. In this respect, EM IT countries with higher external financial vulnerability may be more prone to attempt to stabilize the exchange rate, making their exchange rate regimes less flexible, compared to other IT countries. Figure 1 which examines the correlation between IT and ERR conditional on various macroeconomic conditions shows that IT countries with higher ratio of bank foreign liabilities/total assets, have on average less flexible ERR, compared with the others (first panel, right chart).

\section{B. External Debt}

External indebtedness in emerging markets remains high despite the recent surge in foreign holdings of local-currency government bonds. In this context, exchange rate flexibility might be viewed as undesirable since it contributes to increasing uncertainty about the ability to service the debt, and can undermine debt sustainability and economic stability. An implication for our analysis is that IT countries with higher total external debt (as a share of GDP $)^{4}$ will seek to intervene more frequently than other IT countries to better control the nominal exchange rate in order to prevent the related risks. As shown in Figure 1 (middle panel, left chart), when the IT country sample is divided into groups of countries with high external debt versus others, the ERR is skewed toward rigidity and flexibility, respectively.

\footnotetext{
${ }^{3}$ The 2008/09 global financial crisis showed how severely domestic financial sectors can be affected by an international financial shock.

${ }^{4}$ As an alternative measure, we consider the total external debt as a share of exports receipts of goods and services, and that does not change the results.
} 
These correlations imply that higher external debt (foreign currency-denominated debt) is associated with the "fear of floating," making IT countries less committed to flexibility.

\section{Financial Development}

The degree of financial development can mitigate the risks related to exchange rate fluctuations by providing access to hedging instruments (Aghion et al., 2009). In this regard, IT countries with the most developed financial sectors may be less inclined to control the exchange rate for financial stability purposes. Moreover, financial development improves the transmission mechanisms of monetary policy, making it more likely that there is an independent monetary authority, thereby increasing the likelihood of the move toward a more flexible ERR. Greater financial development is also often perceived as a necessary precondition for an effective and efficient inflation targeting regime. IT countries with better developed financial sectors can be expected to perform better in meeting their inflation objectives and will therefore be less prone to intervene to control the exchange rate. As stated in Stone et al. (2009), financial development improves policy implementation by reducing the dependence on FX intervention.

\section{Inflation and Exchange Rate Pass-Through}

Compared to advanced economies, emerging markets have been relatively less successful in achieving their inflation objectives. This has to do with domestic macroeconomic and institutional conditions, but also with their higher vulnerability to external shocks.

\section{Inflation rate}

Although emerging market IT countries perform better in stabilizing inflation than their peers (see for example Vega and Winkelried, 2005; Mishkin and Schmidt-Hebbel 2007, Gonçalves and Salles, 2008; and Lin and Ye, 2009), they often miss the announced inflation targets over protracted periods of time. As a result, emerging market IT countries with poorer track record in stabilizing inflation (high inflation rates) would be more prone to manipulating the exchange rate in order to cope with potential external shocks and to improve their inflation performance, especially in countries where the exchange rate pass-through is high and where monetary policy transmission is weak. So we would expect that ERR would be less freely floating in those countries, compared to IT countries which perform better in meeting their inflation objective.

\section{Net imports}

Usually, the higher the net imports (as a share of GDP), the stronger the pass-through of imported inflation pressure. In such cases, imported inflation could complicate the achievement of inflation target. In this respect, inflation targeting countries that have a greater exchange rate pass-through (higher imported inflation) may be more prone to controlling exchange rate fluctuations. Consequently, the exchange rate regime would be less flexible in these countries. 
However, the preliminary statistical analysis of the correlation between IT and ERR conditional on the level of inflation and net imports as presented in Figure 1 (lower panel) appears to be inconclusive.

\section{E. Economic Openness}

The degree of economic openness is another important determinant which could explain differences in the degree of flexibility of ERR among EM IT countries. Here we mainly focus on trade and financial openness.

According to the "impossible trinity" hypothesis, the three objectives of independent monetary policy, capital mobility, and exchange rate stabilization cannot be achieved simultaneously. Since central bank independence is a crucial precondition for the adoption of the IT framework, and given that emerging market IT countries are, on average, more financially integrated into the global financial system than their non-targeting counterparts (suggesting greater financial openness), their ability to maintain a stable exchange rate will be more restricted. In this respect, more financially open IT countries are expected to have less room for exchange rate control (it would be too costly in terms of FX reserve management), and so would be more likely to move towards a more flexible exchange rate regime. ${ }^{5}$ We argue that trade openness may work in the same way.

In Figure 1 (middle panel, right chart), financial openness (here capturing a wide range of indicators of the degree of capital mobility) indeed seems to matter for the flexibility of the exchange rate. The ERR seems to be more flexible in countries that impose fewer restrictions on international capital mobility, suggesting a clear and perhaps credible policy commitment to both financial integration and macroeconomic adjustment through exchange rate flexibility. It also validates the "impossible trinity" hypothesis whereby countries seeking to fully take advantage of independent monetary policy (e.g., the IT countries) and allowing capital mobility cannot afford to control closely the level of the nominal exchange rate.

\section{EMpirical Framework: ORdered Probit/Logit Models}

This section presents the baseline econometric approach used to test our hypotheses and discusses the results.

\section{A. The Model}

The choice of an exchange rate regime by country $i$ in period $t$ is described using a discrete variable $y_{i t}$ which, as discussed above, can take four values from 1 to 4 (higher values indicating greater flexibility). $y_{i t}=1$ captures the less flexible regime (peg), and $y_{i t}=4$ the most flexible regime (freely floating). This choice is based on a latent variable $y_{i t}^{*}$ which is a function of economic and institutional determinants of the exchange rate regime. It is

\footnotetext{
${ }^{5}$ We used a de facto index of financial openness, calculated as the sum of external financial assets and liabilities in percentage of GDP.
} 
assumed that a country chooses a specific regime if the latent variable falls below, within or above certain thresholds $\left(c_{1}, c_{2}\right.$ and $\left.c_{3}\right)$ as follows:

$y_{i t}= \begin{cases}1, & \text { if } y_{i t}^{*}<c_{1} \\ 2, & \text { if } c_{1}<y_{i t}^{*}<c_{2} \\ 3, & \text { if } c_{2}<y_{i t}^{*}<c_{3} \\ 4, & \text { if } y_{i t}^{*}>c_{3}\end{cases}$

with $c_{1}<c_{2}<c_{3}$. These unknown thresholds are to be estimated along with the other parameters of the model which takes the form of:

$y_{i t}^{*}=X_{i t}^{\prime} \beta+\alpha I T+\delta I T_{i t} * \tilde{z}_{i t}+\varphi z_{i t}+\varepsilon_{i t} \quad$ for $i=1,2 \ldots N$ and $t=1,2 \ldots T_{i}$

Where $X_{i t}$ is the vector of the most common determinants of the exchange rate regime, $I T_{i t}$ is a dummy variable equal to 1 for country $i$ in period $t$ if the country is classified as an IT country and 0 otherwise, $z_{i t}$ is a conditional variable that is expected to modify the effect of $I T$ on the exchange rate regime (with $\tilde{z}_{i t}$ the difference between $z_{i t}$ and its sample mean), ${ }^{6}$ and $\varepsilon_{i t}$ is an error term which is assumed to follow a logistic or normal distribution. $N$ is the number of countries and $T_{i}$ the total number of observations available for country $i$. Equation 1 therefore describes the structure of our estimated model and we are particularly interested in the effect of inflation targeting on the exchange rate regime. Ordered latent models are used (ordered probit or logit) and country-specific effects are controlled for by the means of random effects.

\section{Standard determinants of the exchange rate regime (vector $\mathrm{X}$ )}

Relying on the existing literature (Edwards, 1996; Rizzo, 1998; Méon and Rizzo, 2002; von Hagen and Zhou, 2005; Markiewicz, 2006; von Hagen and Zhou, 2007; Güçlü, 2008, among others), we control for a set of nine variables considered as common determinants of the choice of the exchange rate regime. These include:

Trade openness - we use the sum of a country's exports and imports as a percentage of GDP as a proxy for trade openness. The traditional approach based on the theory of optimum currency areas (Mundell, 1961; McKinnon, 1963) suggests that pegged regimes are more suitable for countries characterized by high trade openness because a stable exchange rate facilitates trade. In this respect, trade openness is expected to be negatively correlated with our measure of exchange rate flexibility.

\footnotetext{
${ }^{6}$ This specification is used to reduce the co-linearity between the interaction term and $z_{i t}$, but also to ease the interpretation of the interaction.
} 
Financial openness - is an index measuring capital mobility. Just as for trade, emerging markets with higher capital openness can be expected to attempt to control exchange rate fluctuations since this would promote stability in the international financial transactions and will help safeguard their financial system.

Economic development - captures the country's economic development as measured by the log of real GDP per capita in constant U.S. dollar. The costs associated with the creation and the maintenance of a central bank with independent monetary policy will be higher in less developed countries. In addition, the optimum currency areas theory predicts that more developed countries are more likely to float. Consequently, higher economic development is expected to increase the likelihood of adopting and maintaining a flexible exchange rate regime.

Growth - measures the annual growth of GDP and aims to control for countries' economic growth or business cycle conditions. As suggested by Edwards (1996), the growth in GDP can provide indications about countries' real economic "ambition," for example regarding the reduction of unemployment. In this sense, countries that grow faster will tend to tie their hands by adopting fixed exchange rate regimes to solve the potential credibility problem. Furthermore, good economic performances can be expected to favor the accumulation of FX reserves, necessary to maintain a fixed regime. These arguments all suggest that Growth is expected to be negatively correlated with exchange rate flexibility.

Financial development - captures the degree of financial development. Low financial development should be associated with less flexible regimes because countries with less sophisticated financial sectors will lack the necessary infrastructures for monetary authorities to conduct open market operations. The banking system credit provided to the private sector (as a share of GDP) is used as proxy for financial development.

Inflation - is the annual rate of growth of the consumer price index. Large increases in inflation or big inflation shocks make fixed exchange rate regimes less sustainable and require exchange rate adjustments to realign the relative prices. As a consequence, economies experiencing persistent high inflation will be less inclined to keep fixed exchange rate regimes.

FX reserves - is our measure of international exchange reserves coverage (total reserves in months of imports) and is expected to be negatively correlated with the probability of adopting a flexible exchange rate regime. The availability of FX reserves is particularly important for the viability and the credibility of pegged exchange rate regimes, as it provides the monetary authorities with some room to maintain the parity in case of shocks.

Fiscal position - is a variable which captures the country's fiscal position. In particular, we control for the change in total government debt as a share of GDP, which is used as a proxy for the public deficit as a share of GDP. ${ }^{7}$ An increase in the fiscal deficit increases the

\footnotetext{
${ }^{7}$ We use the change in government debt because these data are more available (in terms of time dimension and sample coverage) than fiscal surplus/deficit data.
} 
domestic interest rate and consequently, makes it less easy to maintain fixed exchange rate parity. A higher fiscal deficit can be expected to reduce the likelihood of fixing the exchange rate.

Politics - is introduced to control for political stability following Edwards (1996), and Méon and Rizzo (2002) who suggest that political instability can play an important role in determining the choice of an exchange rate regime. In particular these two papers find that countries with high political instability are less likely to adopt a fixed exchange rate regime.

\section{The conditional variables $(z)$}

In equation (1) the effect of IT is expected to be positive, suggesting that on average the exchange rate regime is more flexible in emerging market IT countries, compared with their non-IT countries' counterparts. However, we argue that this positive correlation is likely to be affected by some macroeconomic conditions (captured by the interaction terms in our empirical framework). Particularly, from equation (1) and assuming a specification building on a linear probability model, the marginal impact of IT is derived as follows:

$$
\frac{\partial y_{i t}^{*}}{\partial I T_{i t}}=\alpha+\delta \tilde{z}_{i t}
$$

This expression gives the effect of inflation targeting for IT countries whose $z_{i t}$ deviates from the sample mean, while $\alpha$ captures the effect of inflation targeting for IT countries whose $z_{i t}$ is equal to the mean $\left(\tilde{z}_{i t}=0\right)$.

First, following our discussion in the previous section, if we consider macroeconomic conditions that can make IT countries less likely to adopt a freely floating exchange rate regime (factors reducing the positive effect of $I T$ on exchange rate flexibility), these may include Bank foreign assets to total assets ratio, Bank foreign liabilities to total assets ratio, External debt, Inflation rate, and Net imports. Considering those factors as conditional variables in our empirical framework, $\delta$ is expected to be negative, suggesting lower flexibility of the ERR in inflation targeting countries.

Next, some other characteristics of inflation targeting countries can be expected to increase the likelihood of a choice of a more flexible ERR (factors reinforcing the effect of IT on exchange flexibility). Also following our previous discussion, these factors include Financial development, Trade, and Financial openness. With these factors as conditional variables, $\delta$ is expected to be positive, suggesting higher exchange rate flexibility in inflation targeting countries.

In addition to the above macroeconomic conditions, the following factors may also play a role in determining the relative degree of exchange rate flexibility:

Time- - the length of time since the adoption of inflation targeting

Most emerging markets implementing the inflation targeting strategy do not satisfy the required preconditions at the time of its adoption. Consequently, due to the lack of sound 
initial macroeconomic and institutional conditions, these countries tend to remain in relatively fixed exchange rate regimes, even after the public announcement of the adoption of IT. They then move to more flexible regimes later, when these conditions improve. This suggests that, countries that have implemented inflation targeting for a longer period of time may be inclined to allow greater exchange rate flexibility, compared to countries that have adopted the IT strategy more recently. Stone et al. (2009) support this argument for emerging countries by highlighting the role of the exchange rate during the transition to a full-fledged inflation targeting framework.

\section{The probability of adopting inflation targeting}

Adopting inflation targeting as a monetary policy framework should increase the probability of having a flexible exchange rate regime. However, it can be argued that those countries that better meet the preconditions of this policy adoption may be more prone to exchange rate flexibility in the first place. Following Lin and Ye (2009), we test this hypothesis by interacting the IT dummy with the Pscore which is the predicted probability of adopting inflation targeting explained by a large set of pre-determined macroeconomic conditions (the higher the Pscore, the more likely it is that the preconditions are met). The estimation of the Pscores is discussed in more details in section IV.

\section{B. Results}

Since the values taken by our dependent variable (the choice of an exchange rate regime) can be ordered logically (from fixed to flexible), equation (1) is estimated using random-effects ordered probit to control for unobserved country-specific heterogeneity. All explanatory variables (except the IT dummy) are included with one year lag to reduce the potential bias due to reverse causality. ${ }^{8}$

From Table 1, the results suggest that most of the coefficients associated with the standard determinants of the exchange rate regime appear to be significant with the expected sign. Among the most relevant variables, trade openness, economic growth, FX reserves, and financial openness are found to have a negative effect on the probability of adopting a flexible exchange rate regime. In other words, in emerging countries an increase in these variables will favor pegged exchange rate regimes. On the contrary, the findings show that inflation rate is positively correlated with the probability of adopting more flexible regimes. As discussed above, high inflation impairs the sustainability of pegs and can generate large costs arising from the required exchange rate adjustments. So increasing inflation will tend to be associated with flexible regimes. The effect of these determinants proves to be robust to the various specifications of the estimated model presented in Table 1.

Economic development and political stability also affect the choice of the exchange rate regime, although their effects are much less robust to alternative model specifications. The increase in countries' economic development is associated with a higher probability to adopt

\footnotetext{
${ }^{8}$ Since we are not interested in measuring the magnitude of the effect of IT on ERR, but rather the direction of causality, we do not derive the marginal effects from the probit and logit models.
} 
more flexible regimes. On the contrary, political stability is found to have a negative effect on exchange rate flexibility. The coefficients associated with financial development and public deficit are not statistically significant.

These are consistent with the theoretical argumentation and broadly in line with previous empirical works. Now we turn to the main interest of the paper which is the effect of inflation targeting.

The effect of the IT dummy is almost always strongly significant and positive, suggesting that the adoption of inflation targeting increases the probability of having a flexible exchange rate regime. That is to say, on average, IT countries float relatively more than non-IT countries.

We now examine the existence of possible non-linearities in the effect of the IT regime on the choice of the exchange rate regime in EMs. Table 1 shows that the coefficients associated with the interaction terms between IT and Trade openness, Financial openness, and Financial development are all positive and significant at the 1 percent significance level. While implementing inflation targeting increases the flexibility of the exchange rate regime, this result suggests that IT countries, which are on average more open financially and economically, float more than the others. As discussed above, this can be related to the "impossible trinity" hypothesis which suggests that an independent monetary policy coupled with capital mobility are incompatible with a pegged ERR. As a result, the higher the openness of the IT country's capital account, the higher the probability of floating. The positive effect of the interaction term between IT and financial development suggests that for IT countries whose financial development is above the sample average, the flexibility of the exchange rate regime is greater. The degree of financial development improves the effectiveness of inflation targeting by facilitating the transmission mechanisms of monetary policy, and so making it less necessary to control the exchange rate (as a means of adjustment for monetary policy). 


\begin{tabular}{|c|c|c|c|c|c|c|c|c|c|c|c|}
\hline \multicolumn{12}{|c|}{ Table 1. Random Effects Ordered Probit Estimates } \\
\hline & (1) & (2) & (3) & (4) & (5) & $(6)$ & (7) & (8) & (9) & $(10$ & (11) \\
\hline IT & $\begin{array}{c}1.374 * * * \\
(7.503)\end{array}$ & $\begin{array}{c}1.375^{* * *} \\
(7.528)\end{array}$ & $\begin{array}{c}1.535^{* * *} \\
(7.222)\end{array}$ & $\begin{array}{c}1.289 * * * \\
(6.930)\end{array}$ & $\begin{array}{c}0.680 * * \\
(2.378)\end{array}$ & $\begin{array}{c}0.456 \\
(1.416)\end{array}$ & $\begin{array}{c}0.432 \\
(1.440)\end{array}$ & $\begin{array}{c}1.477 * * * \\
(7.174)\end{array}$ & $\begin{array}{c}1.224 * * * \\
(6.065)\end{array}$ & $\begin{array}{c}1.392 * * * \\
(6.754)\end{array}$ & $\begin{array}{c}0.382 \\
(1.549)\end{array}$ \\
\hline IT*Trade openness & & $\begin{array}{l}0.0134 * * * \\
(2.800)\end{array}$ & & & & & & & & & \\
\hline IT* Financial openness & & & $\begin{array}{l}0.0194 * * * \\
(3.827)\end{array}$ & & & & & & & & \\
\hline Financial openness & & & $\begin{array}{c}-0.0140 * * * \\
(-2.907)\end{array}$ & & & & & & & & \\
\hline IT* Financial development & & & & $\begin{array}{l}0.0175^{* * *} \\
(3.701)\end{array}$ & & & & & & & \\
\hline IT*Bank foreign assets/total assets & & & & & $\begin{array}{c}-0.0331 * * \\
(-2.163)\end{array}$ & & & & & & \\
\hline Bank foreign assets/total assets & & & & & $\begin{array}{c}-0.00709 \\
(-1.478)\end{array}$ & & & & & & \\
\hline IT*Bank foreign liabilities/total assets & & & & & & $\begin{array}{c}-0.00846 * * * \\
(-2.635)\end{array}$ & & & & & \\
\hline Bank foreign liabilities/total assets & & & & & & $\begin{array}{c}-0.00275 \\
(-0.488)\end{array}$ & & & & & \\
\hline IT*Inflation & & & & & & & $\begin{array}{c}-0.141 * * * \\
(-3.898)\end{array}$ & & & & \\
\hline IT* Net imports & & & & & & & & $\begin{array}{c}-0.0971 * * * \\
(-4.759)\end{array}$ & & & \\
\hline Net imports & & & & & & & & $\begin{array}{c}-0.0349 * * * \\
(-3.446)\end{array}$ & & & \\
\hline IT*External debt & & & & & & & & & $\begin{array}{c}-0.0193 * * * \\
(-2.677)\end{array}$ & & \\
\hline External debt & & & & & & & & & $\begin{array}{c}0.0153^{* * *} \\
(4.443)\end{array}$ & & \\
\hline IT*Pscore & & & & & & & & & & $\begin{array}{c}2.179 * * \\
(2.368)\end{array}$ & \\
\hline Pscore & & & & & & & & & & $\begin{array}{c}-1.775^{* *} \\
(-1.992)\end{array}$ & \\
\hline IT*Time & & & & & & & & & & & $\begin{array}{c}0.218^{* * * *} \\
(5.796)\end{array}$ \\
\hline Trade openness & $\begin{array}{c}-0.00529 * \\
(-1.719)\end{array}$ & $\begin{array}{c}-0.00895 * * * \\
(-2.627)\end{array}$ & $\begin{array}{c}-0.000808 \\
(-0.214)\end{array}$ & $\begin{array}{c}-0.00497 \\
(-1.573)\end{array}$ & $\begin{array}{c}-0.00518 \\
(-1.642)\end{array}$ & $\begin{array}{c}-0.00605^{*} \\
(-1.915)\end{array}$ & $\begin{array}{c}-0.00560^{*} \\
(-1.787)\end{array}$ & & $\begin{array}{c}-0.00574 \\
(-1.502)\end{array}$ & $\begin{array}{c}-0.00628^{*} \\
(-1.875)\end{array}$ & $\begin{array}{c}-0.00687 * * \\
(-2.142)\end{array}$ \\
\hline Growth & $\begin{array}{c}-0.0343 * * \\
(-2.309)\end{array}$ & $\begin{array}{c}-0.0372 * * \\
(-2.499)\end{array}$ & $\begin{array}{c}-0.0368 * * \\
(-2.444)\end{array}$ & $\begin{array}{c}-0.0341 * * \\
(-2.283)\end{array}$ & $\begin{array}{c}-0.0359^{* *} \\
(-2.300)\end{array}$ & $\begin{array}{c}-0.0363^{* *} \\
(-2.319)\end{array}$ & $\begin{array}{c}-0.0357 * * \\
(-2.393)\end{array}$ & $\begin{array}{c}-0.0272 * \\
(-1.688)\end{array}$ & $\begin{array}{l}-0.0218 \\
(-1.384)\end{array}$ & $\begin{array}{c}-0.0472 * * * \\
(-2.671)\end{array}$ & $\begin{array}{c}-0.0329 * * \\
(-2.189)\end{array}$ \\
\hline Economic development & $\begin{array}{c}0.182 \\
(0.934)\end{array}$ & $\begin{array}{c}0.206 \\
(1.051)\end{array}$ & $\begin{array}{c}0.259 \\
(1.252)\end{array}$ & $\begin{array}{c}0.217 \\
(1.060)\end{array}$ & $\begin{array}{c}0.114 \\
(0.557)\end{array}$ & $\begin{array}{l}0.0747 \\
(0.363)\end{array}$ & $\begin{array}{c}0.191 \\
(0.954)\end{array}$ & $\begin{array}{l}-0.0806 \\
(-0.352)\end{array}$ & $\begin{array}{l}0.440^{*} \\
(1.647)\end{array}$ & $\begin{array}{l}0.357 * \\
(1.657)\end{array}$ & $\begin{array}{l}0.0883 \\
(0.447)\end{array}$ \\
\hline Financial development & $\begin{array}{l}8.21 \mathrm{e}-05 \\
(0.0221)\end{array}$ & $\begin{array}{c}0.000269 \\
(0.0721)\end{array}$ & $\begin{array}{c}0.000538 \\
(0.142)\end{array}$ & $\begin{array}{c}-0.00717 * \\
(-1.657)\end{array}$ & $\begin{array}{c}0.000444 \\
(0.118)\end{array}$ & $\begin{array}{c}0.00164 \\
(0.433)\end{array}$ & $\begin{array}{c}-0.00122 \\
(-0.323)\end{array}$ & $\begin{array}{c}-0.000160 \\
(-0.0407)\end{array}$ & $\begin{array}{c}-0.00303 \\
(-0.707)\end{array}$ & $\begin{array}{c}0.000818 \\
(0.202)\end{array}$ & $\begin{array}{c}-0.00189 \\
(-0.497)\end{array}$ \\
\hline Inflation & $\begin{array}{c}0.0177 * * * \\
(3.337)\end{array}$ & $\begin{array}{c}0.0155^{* * *} \\
(2.874)\end{array}$ & $\begin{array}{c}0.0196^{* * * *} \\
(3.741)\end{array}$ & $\begin{array}{c}0.0146^{* * *} \\
(2.703)\end{array}$ & $\begin{array}{c}0.0188 * * * \\
(3.569)\end{array}$ & $\begin{array}{c}0.0193 * * * \\
(3.662)\end{array}$ & $\begin{array}{c}0.0178 * * * \\
(3.347)\end{array}$ & $\begin{array}{c}0.0149 * * * \\
(2.641)\end{array}$ & $\begin{array}{c}0.0173 * * * \\
(2.902)\end{array}$ & $\begin{array}{c}0.0158^{* *} \\
(1.994)\end{array}$ & $\begin{array}{c}0.0175^{* * *} \\
(3.256)\end{array}$ \\
\hline
\end{tabular}




\begin{tabular}{|c|c|c|c|c|c|c|c|c|c|c|c|}
\hline Reserves & $\begin{array}{c}-0.0590 * * * \\
(-3.107)\end{array}$ & $\begin{array}{c}-0.0580 * * * \\
(-3.053)\end{array}$ & $\begin{array}{c}-0.0460 * * \\
(-2.382)\end{array}$ & $\begin{array}{c}-0.0699 * * * \\
(-3.576)\end{array}$ & $\begin{array}{c}-0.0640 * * * \\
(-3.122)\end{array}$ & $\begin{array}{c}-0.0625^{* * *} \\
(-3.023)\end{array}$ & $\begin{array}{c}-0.0651 * * * \\
(-3.370)\end{array}$ & $\begin{array}{c}-0.0872 * * * \\
(-4.052)\end{array}$ & $\begin{array}{c}-0.0492 * * \\
(-2.367)\end{array}$ & $\begin{array}{c}-0.0722 * * * \\
(-3.621)\end{array}$ & $\begin{array}{c}-0.0632 * * * \\
(-3.254)\end{array}$ \\
\hline Capital openness & $\begin{array}{c}-0.139 * * \\
(-2.462)\end{array}$ & $\begin{array}{c}-0.166 * * * \\
(-2.903)\end{array}$ & & $\begin{array}{c}-0.151 * * * \\
(-2.640)\end{array}$ & & & $\begin{array}{c}-0.176^{* * *} \\
(-3.053)\end{array}$ & $\begin{array}{c}-0.206^{* * *} \\
(-3.356)\end{array}$ & $\begin{array}{l}-0.0479 \\
(-0.768)\end{array}$ & $\begin{array}{c}-0.155^{* * *} \\
(-2.604)\end{array}$ & $\begin{array}{c}-0.254 * * * \\
(-4.179)\end{array}$ \\
\hline Politics & $\begin{array}{l}-0.0123 \\
(-1.471)\end{array}$ & $\begin{array}{l}-0.0103 \\
(-1.223)\end{array}$ & $\begin{array}{l}-0.0126 \\
(-1.494)\end{array}$ & $\begin{array}{c}-0.00858 \\
(-1.007)\end{array}$ & $\begin{array}{c}-0.0176^{* *} \\
(-1.988)\end{array}$ & $\begin{array}{c}-0.0150^{*} \\
(-1.712)\end{array}$ & $\begin{array}{l}-0.0114 \\
(-1.351)\end{array}$ & $\begin{array}{c}-0.00429 \\
(-0.466)\end{array}$ & $\begin{array}{c}-0.0177^{*} \\
(-1.935)\end{array}$ & $\begin{array}{l}-0.0101 \\
(-1.149)\end{array}$ & $\begin{array}{c}-0.00463 \\
(-0.539)\end{array}$ \\
\hline Fiscal & $\begin{array}{c}0.00252 \\
(0.449)\end{array}$ & $\begin{array}{l}0.00156 \\
(0.278)\end{array}$ & $\begin{array}{l}0.00365 \\
(0.649)\end{array}$ & $\begin{array}{c}0.00280 \\
(0.499)\end{array}$ & $\begin{array}{c}0.00167 \\
(0.296)\end{array}$ & $\begin{array}{c}0.00107 \\
(0.191)\end{array}$ & $\begin{array}{c}0.00130 \\
(0.231)\end{array}$ & $\begin{array}{c}0.00274 \\
(0.432)\end{array}$ & $\begin{array}{c}-0.000374 \\
(-0.0616)\end{array}$ & $\begin{array}{c}-0.00386 \\
(-0.475)\end{array}$ & $\begin{array}{c}0.00260 \\
(0.458)\end{array}$ \\
\hline Observations & 640 & 640 & 642 & 640 & 594 & 594 & 640 & 588 & 624 & 602 & 640 \\
\hline Number of id & 36 & 36 & 36 & 36 & 35 & 35 & 36 & 36 & 36 & 35 & 36 \\
\hline Wald chi2 stat & 88.33 & 95.72 & 89.58 & 97.43 & 78.09 & 78.72 & 100.5 & 117.5 & 96.31 & 90.27 & 113.4 \\
\hline
\end{tabular}


On the contrary, the interaction terms between IT and Inflation, Net imports, External debt, Bank foreign assets/total assets, and Bank foreign liabilities/total assets ratios all exhibit strong significant but negative effects. This suggests that IT countries with levels of inflation and net imports above the sample average exhibit less exchange rate flexibility compared to other IT countries. IT countries may be willing to control the exchange rate fluctuations if they are highly dependent on imports, since such dependence makes the domestic economy more vulnerable to external shocks and is associated with a higher exchange rate passthrough. Regarding the level of inflation, if an IT central bank finds difficult to achieve its inflation stabilization objective, it may be willing to control the exchange rate variations in order to limit the size of the exchange rate pass-through into inflation. ${ }^{9}$ When it comes to external debt and the ratios of banking sector foreign assets to total assets and foreign liabilities to total assets, the negative sign of the interaction terms between these variables and IT suggests that IT countries more vulnerable to external shocks are less likely to have a freely floating ERR. We argued that a high level of external debt (especially foreign currency-denominated debt), may generate more concerns regarding exchange rate fluctuations, making IT countries more prone to attempt to stabilize the exchange rate. The banking sector balance sheet exposure to external shocks and currency mismatch is another important concern in EMs. Our findings show that those IT countries whose banking sectors are the most vulnerable to such risks are more prone to FX interventions. ${ }^{10}$

Finally, we investigate whether the effect of the IT strategy on the choice of exchange rate regime varies with the probability of adopting IT, and with the maturity of the IT in place. The coefficients associated with the interaction terms between IT, Pscore (the probability of adopting inflation targeting), and Time (the number of year since the adoption of the inflation targeting strategy), are positive and significant. ${ }^{11}$ IT countries which better meet the preconditions of policy adoption (with a Pscore higher than the sample average) are more likely to float. Also, longer implementation of inflation targeting increases the probability of floating. This can be perceived as a "learning-by-doing" effect in practicing inflation targeting.

\section{Robustness Checks}

We conduct a number of robustness checks for these results. First, the baseline model is reestimated using random effect-ordered logit instead of the ordered probit. The results presented in Table 2 show that our main conclusions regarding the standard determinants of

\footnotetext{
${ }^{9}$ Note that we also test the interaction between IT and inflation volatility and we reach the same conclusion: the interaction term exhibits a negative and significant effect, suggesting that IT countries with higher inflation volatility have a lower probability to adopt a freely floating exchange rate regime.

${ }^{10}$ Note that as an alternative to the two ratios related to the banking system balance sheet used in this empirical exercise, we test the interaction terms between IT and the growth rate of bank foreign assets and the growth rate of bank foreign liabilities. The findings support our conclusions that higher exposure of the financial system to external shocks (higher growth rates) is associated with lower flexibility of the ERR in IT countries.

${ }^{11}$ While the general rule requires that both interacted variables should be included in the regression, we do not include Time because its values are the same as those of the interaction term.
} 
the exchange rate regime (not reported), as well as the effect of inflation targeting, remain broadly unchanged.

Second, we control for some additional variables in order to better test the resilience of the previous estimates. In particular, we include dummy variables which capture currency crises, banking crises, and sovereign debt crises. While these dummies are found to have no effect on the exchange rate regime, the effects of the other variables remain in line with our main findings (see Appendix Table 4). We also control for the degree of central bank independence, a factor which may be jointly correlated with $I T$ and the choice of exchange rate regime. The results suggest that the coefficient associated with the index of central bank independence is positive but not statistically significant, while our main results regarding the effects of IT on exchange rate regimes remain unchanged (see Appendix Table 5).

Another important issue regarding the empirical framework used so far is the relevance and interpretation of interaction effects in nonlinear models such as probit or logit. While many empirical studies rely on such analytical frameworks, it can be argued that the interaction effects produced by standard software may be misleading (see Ai and Norton, 2003). As an alternative approach, we used the linear probability model to investigate the conditional effects of inflation targeting on exchange rate regime. ${ }^{12}$ Hence, we re-estimate the baseline equation 1 (the dependent variable being the cardinal de facto exchange rate regime variable) using OLS panel fixed effects. The results presented in Appendix Table 6 are in line with findings from nonlinear models. Inflation targeting has a positive and significant effect on exchange rate flexibility. Also, all the interaction terms exhibit strong significant effects, with expected signs.

\footnotetext{
${ }^{12}$ Similar approaches have been used in the empirical literature dealing with interaction effects when the dependent variable is not continuous (see for example the paper from Martin et al., 2012 on trade agreements).
} 
Overall, the robustness checks produce reassuring results which show that the existence of non-linear effects of IT is robust to alternative estimators (probit, logit and linear probability models), various types of country-specific heterogeneity (fixed $v s$ random effects), and a large range of additional control variables.

\section{Propensity Score Matching Estimates}

An issue in empirical analyses which seek to compare inflation targeting and non-targeting countries is the possible self-selection bias surrounding the adoption and the implementation of the IT regime. The choice of adopting a particular monetary policy strategy such as inflation targeting is not random, and may depend on a country's macroeconomic and institutional characteristics (prerequisites for a successful and credible regime). Ignoring or failing to take this bias into account could result in severe biases in the estimates. But also, addressing or limiting the extent of the bias is a challenging task in the absence of natural experiments, credible instrumental variables, or a pure randomized control strategy. We follow the literature on macro impact evaluations and make use of the propensity score matching techniques (PSM). Earlier papers focusing on the macroeconomic consequences of the adoption of inflation targeting have provided robust estimates using this framework (Vega and Winkelried, 2005; Lin and Ye, 2007; Lin, 2010, among others).

\section{A. Model}

We are interested in evaluating the effect of a treatment (the implementation of an inflation targeting regime) on the treated (the group of inflation targeting countries) regarding a specific outcome (the degree of exchange rate flexibility). This average treatment effect on the treated (ATT) can be estimated as follows:

$$
A T T=E\left[Y_{i}^{1} \mid T_{i}=1\right]-E\left[Y_{i}^{0} \mid T_{i}=1\right]
$$

where $\mathrm{T}$ is a dummy variable equal to 1 for an inflation targeting country.

The expression $Y_{i}^{1} \mid T_{i}=1$ represents the value of the outcome observed for an IT country and $Y_{i}^{0} \mid T_{i}=1$ is the value of this outcome if the same country had not adopted inflation targeting. However, the difficulty in estimating equation (2) is that the latter value of the outcome is not observed. If the treatment is randomly distributed, the ATT can be derived as a simple average difference in outcomes between treated and non-treated (IT countries versus non-IT countries). The PSM therefore offers an alternative way to estimate the ATT. The PSM is based on the fundamental assumption that, conditional on certain observable characteristics, $\mathrm{W}$, the outcome should be independent of the treatment $\left(Y^{0}, Y^{1} \perp T \mid W\right)$. Assuming the independence condition, the PSM relies on a less restrictive approach, which is to match treated and non-treated on the basis of a score derived as the probability of policy adoption conditional on W (the propensity scores). The ATT can then be estimated using equation (3).

$$
A T T=E\left[Y_{i}^{1} \mid T_{i}=1, p\left(W_{i}\right)\right]-E\left[Y_{i}^{0} \mid T_{i}=0, p\left(W_{i}\right)\right]
$$


where $p\left(W_{i}\right)=\operatorname{Pr}\left(T_{i}=1 \mid W_{i}\right)$ is the probability of adopting inflation targeting, which can be estimated using probit or logit models.

We consider a variety of propensity score matching algorithms commonly used in the literature: nearest neighbor matching (which matches treated units to the $\mathrm{n}$ control units with the closest propensity scores), radius matching (which matches treated units to control units with scores falling within a given radius), and kernel matching (which matches treated units to all control units using different weights proportional to the closeness of the control units). For the nearest neighbor matching method, three alternatives are tested: the nearest neighbor, the 3 nearest neighbors, and the 5 nearest neighbors. The radius matching method also relies on three alternative sizes of the radius $(\mathrm{r}): \mathrm{r}=0.1, \mathrm{r}=0.05$ and $\mathrm{r}=0.02$.

For the purpose of estimating the propensity scores, we use a probit model in which the dependent variable is the inflation targeting dummy. The explanatory variables $(W)$ are factors which affect both the adoption of inflation targeting and the degree of exchange rate regime flexibility (the outcome). We control for macroeconomic characteristics affecting both the treatment and the outcome: inflation rate (included with one year lag), trade openness, GDP growth, FX reserves, fiscal deficit, economic development, financial development, and central bank independence. We expect the last three variables to be positively correlated with the probability of adopting inflation targeting, and the others negatively.

In this framework, to investigate the extent to which the effect of IT on the exchange rate regime is affected by macroeconomic conditions (the conditional variables $z$ ), we rely on a simple approach. Considering the sample of IT countries, we determine a threshold level of the conditional variable $z$ (e.g., its median value) and split the targeting observations into two groups (above and below the threshold). We then estimate the ATT for the two groups separately, the non-IT countries sample remaining unchanged and forms part of the control groups. The ATT is expected to be different between the two groups depending on the levels of $z$. More precisely, consider the case where $z$ is external debt. The ATT is expected to be lower for the group of IT countries which have higher external debt (above the median), suggesting that the exchange rate regime is less flexible in those countries with respect to those whose levels of debt is lower (below the median).

\section{B. Results}

The results of the probit model estimations are presented in Appendix Table 7. The control variables are highly significant, except for fiscal deficit. As expected, economic development and central bank independence are associated with higher probability of adopting the IT regime. The effect on the adoption of IT of trade openness, economic growth, lagged inflation, and FX reserves is negative. The effect of financial development seems to be mixed (the coefficients are both positive and negative). The counter-intuitive negative effect of financial development holds when considering the sub-samples of IT countries with higher external debt, lower financial openness, and lower financial development.

Prior to estimating the $A T T$, we ensure that the treated and control groups share the same support. In other words, we try to ensure that the estimated scores are comparable across 
treated and non-treated observations. To this end, we drop all treated units with scores higher than the maximum or lower than the minimum score for the non-treated units. Table 3 presents the main results. From the baseline estimates of the ATT (the average effect of inflation targeting on the exchange rate regime), we find that $I T$ has a positive and significant effect on exchange rate flexibility. This suggests that on average, the exchange rate regime is more flexible in inflation targeting emerging countries, as compared to non-IT countries, a result which echoes the baseline estimates obtained earlier.

As regards the estimated ATT conditional to the levels of $z$, the results suggest that IT countries with lower levels of external debt, lower levels of bank foreign assets, and lower levels of foreign liabilities relative to total bank assets, float relatively more than the others. Indeed, the effect of IT on exchange rate flexibility is lower for those IT countries whose external debt and the two ratios related to the banking system balance sheet exceed the defined threshold (the median). ${ }^{13}$ Similar conclusions hold when the estimated ATT is conditional on the level of inflation and net imports as a share of GDP: IT countries with better inflation performance (good control of inflation) float relatively more than IT countries with higher levels of inflation. The effect of $I T$ on exchange rate flexibility is lower for IT countries with higher levels of inflation. IT countries which are less import-dependent (implying lower exchange rate pass-through) float relatively more than those whose net imports exceed the IT sample median.

When estimating the effect of IT on exchange rate regime conditional on the degree of financial openness, we find that the more financially open IT countries float relatively more than those less integrated into the international financial system. The ATT is lower for the latter. Regarding the impact of IT conditional on trade openness and financial development, our findings based on PSM approach are mixed. There seems to be no significant difference in the ATT estimated for the two groups, based on the level of financial development. Regarding the degree of trade openness, the results suggest that the exchange rate regime is less flexible for IT countries which trade more with the rest of the world.

\footnotetext{
${ }^{13}$ Conclusions are broadly in line with this finding when estimating the ATT conditional to the growth rates of bank foreign assets and bank foreign liabilities.
} 


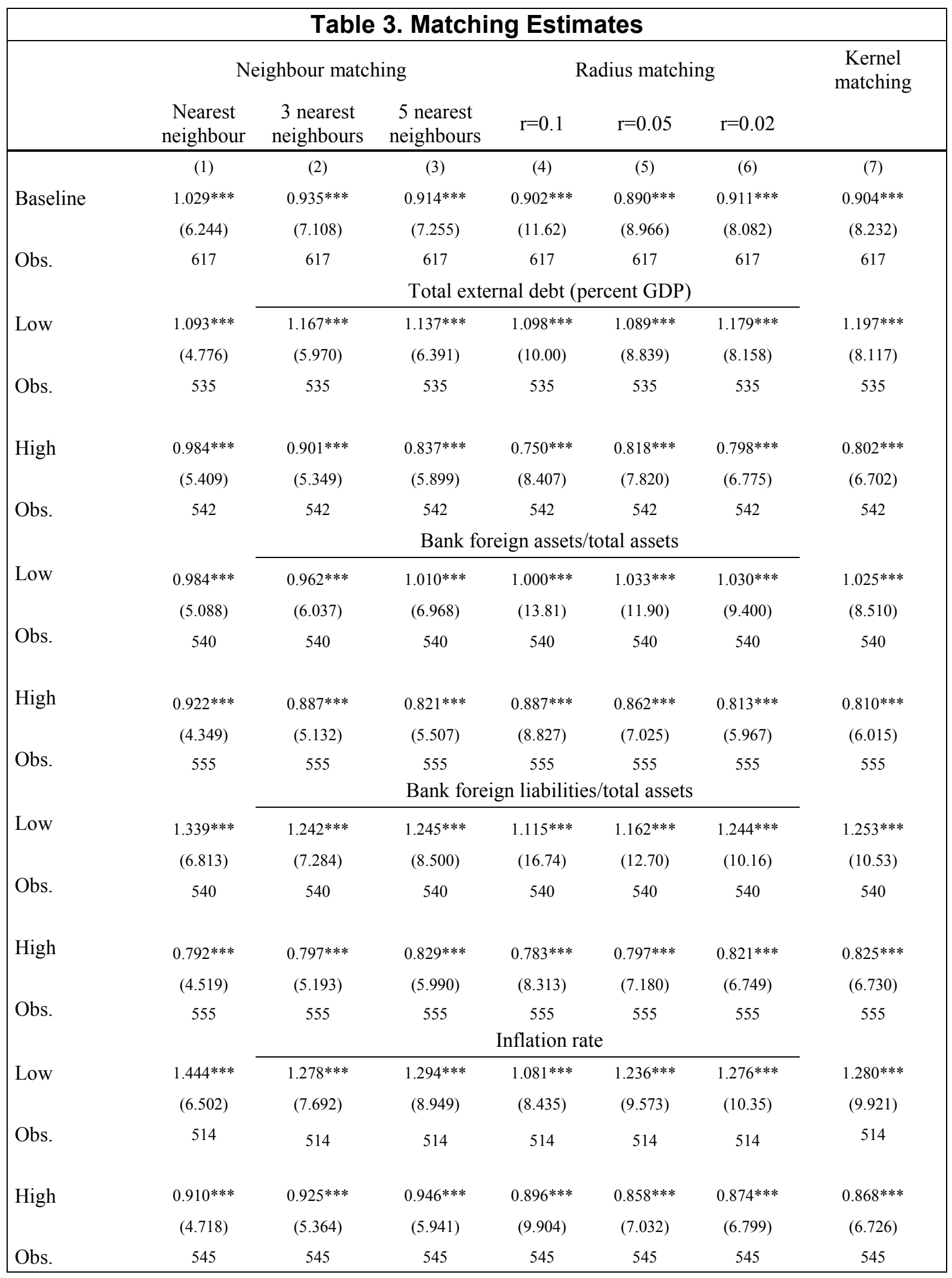




\begin{tabular}{|c|c|c|c|c|c|c|c|}
\hline \multirow[b]{2}{*}{ Low } & \multirow{3}{*}{$\begin{array}{c}1.018 * * * \\
(4.909)\end{array}$} & \multicolumn{4}{|c|}{ Net imports (percent GDP) } & \multirow{3}{*}{$\begin{array}{c}1.062 * * * \\
(9.319)\end{array}$} & \multirow{3}{*}{$\begin{array}{c}1.069 * * * \\
(9.299)\end{array}$} \\
\hline & & $1.117 * * *$ & $1.098^{* * *}$ & $0.973 * * *$ & $1.042 * * *$ & & \\
\hline & & $(6.873)$ & $(7.765)$ & $(12.21)$ & $(11.57)$ & & \\
\hline Obs. & 535 & 535 & 535 & 535 & 535 & 535 & 535 \\
\hline \multirow[t]{2}{*}{ High } & $0.734 * * *$ & $0.776^{* * *}$ & $0.759^{* * *}$ & $0.793^{* * *}$ & $0.763^{* * *}$ & $0.778^{* * *}$ & $0.772 * * *$ \\
\hline & (3.968) & $(4.484)$ & $(4.982)$ & (8.175) & $(6.931)$ & $(5.761)$ & (5.919) \\
\hline Obs. & 542 & 542 & 542 & 542 & 542 & 542 & 542 \\
\hline \multicolumn{8}{|c|}{ Financial openness } \\
\hline \multirow[t]{2}{*}{ Low } & $0.915^{* * *}$ & $0.770 * * *$ & $0.772 * * *$ & $0.781 * * *$ & $0.798 * * *$ & $0.778 * * *$ & $0.781^{* * * *}$ \\
\hline & $(4.905)$ & $(5.116)$ & $(5.371)$ & $(9.138)$ & $(8.070)$ & $(6.926)$ & $(6.519)$ \\
\hline Obs. & 549 & 549 & 549 & 549 & 549 & 549 & 549 \\
\hline \multirow[t]{2}{*}{ High } & $1.169^{* * *}$ & $1.164 * * *$ & $1.194 * * *$ & $1.116^{* * *}$ & $1.168^{* * *}$ & $1.175^{* * *}$ & $1.171^{* * *}$ \\
\hline & $(5.698)$ & $(6.583)$ & $(7.518)$ & $(11.85)$ & $(9.623)$ & $(9.035)$ & $(8.922)$ \\
\hline Obs. & 546 & 546 & 546 & 546 & 546 & 546 & 546 \\
\hline \multicolumn{8}{|c|}{ Trade openness } \\
\hline \multirow[t]{2}{*}{ Low } & $1.368 * * *$ & $1.245 * * *$ & $1.194 * * *$ & $1.142 * * *$ & $1.160 * * *$ & $1.169 * * *$ & $1.168^{* * * *}$ \\
\hline & $(6.852)$ & $(7.657)$ & $(7.862)$ & (11.97) & $(10.69)$ & $(9.118)$ & $(9.130)$ \\
\hline Obs. & 547 & 547 & 547 & 547 & 547 & 547 & 547 \\
\hline \multirow[t]{2}{*}{ High } & $0.957 * * *$ & $0.962 * * *$ & $0.920 * * *$ & $0.841 * * *$ & $0.906^{* * *}$ & $0.930 * * *$ & $0.930 * * *$ \\
\hline & $(4.800)$ & $(5.669)$ & $(6.138)$ & (8.748) & (7.924) & (7.334) & $(6.992)$ \\
\hline Obs. & 548 & 548 & 548 & 548 & 548 & 548 & 548 \\
\hline \multicolumn{8}{|c|}{ Financial development } \\
\hline \multirow[t]{2}{*}{ Low } & $0.944 * * *$ & $0.907 * * *$ & $0.925 * * *$ & $0.878 * * *$ & $0.919 * * *$ & $0.965 * * *$ & $0.967 * * *$ \\
\hline & $(5.369)$ & $(6.311)$ & $(7.183)$ & $(10.95)$ & $(9.080)$ & $(8.706)$ & $(8.579)$ \\
\hline Obs. & 550 & 550 & 550 & 550 & 550 & 550 & 550 \\
\hline \multirow[t]{2}{*}{ High } & $0.741^{* * *}$ & $0.827 * * *$ & $0.889^{* * *}$ & $0.860 * * *$ & $0.916^{* * *}$ & $0.921 * * *$ & $0.911^{* * *}$ \\
\hline & $(3.060)$ & $(3.952)$ & $(4.901)$ & $(6.710)$ & $(5.836)$ & $(5.181)$ & $(5.384)$ \\
\hline Obs. & 548 & 548 & 548 & 548 & 548 & 548 & 548 \\
\hline \multicolumn{8}{|c|}{$\begin{array}{l}\text { A } 0.06 \text { fixed bandwidth and an Epanechnikov kernel are used for kernel regression matching. T-statistics based on bootstrapped standard errors ar } \\
\text { reported in parentheses ( } 500 \text { replications). ***, **, and * indicate statistical significance at the } 1,5 \text {, and } 10 \text { percent levels, respectively. For the } \\
\text { conditional variable considered, "Low" and "High" indicate that IT countries' observations have been restricted to values lower and higher than th } \\
\text { median respectively, the control group remaining unchanged. } \\
\text { Source: IMF staff calculations. }\end{array}$} \\
\hline
\end{tabular}

Overall, the findings based on the PSM approach are broadly in line with those based on the logit and probit baseline estimates. We find that the probability of adopting a flexible exchange rate regime is higher for IT countries. Moreover, among inflation targeting emerging markets, the flexibility of the exchange rate does depend on specific macroeconomic conditions. 


\section{Robustness: Rosenbaum Bounds}

We check the robustness of the results discussed above by testing the sensitivity of the matching estimates to unobserved heterogeneity. As stated in the model's description, the PSM procedure relies on the assumption that treatment selection is based only on observable characteristics (the conditional independence hypothesis). Checking the sensitivity of the results with respect to deviations from this assumption is important. Rosenbaum's (2002) approach determines if a hidden bias can emerge from the estimation of the average treatment effect due to unobserved variables. This procedure is used to carry out the sensitivity analysis.

The Rosenbaum (2002) sensitivity analysis estimates the odds of being treated or not, and determines bounds for the odds ratio, based on a parameter $\Gamma$ that assesses the extent to which the effect of the treatment is affected by unobserved factors. An odds ratio equal to 1 $(\Gamma=1)$ suggests that there is no hidden bias. The Rosenbaum bound analysis then investigates the extent to which increasing values of $\Gamma$ may imply increasing influence of unobserved variables. In particular, the smaller the lowest value of $\Gamma$ producing a confidence interval that includes 0 , the stronger the hidden bias.

The results suggest that our findings based on the PSM approach are highly robust to potential hidden bias. Indeed, with values of $\Gamma$ between 1 and 5, the confidence intervals do not include 0 , implying that even if the unobserved characteristics increase the odds ratio by a factor of 5, there will be no significant effect of hidden bias. The average treatment effect of inflation targeting on the exchange rate regime, estimated with the various considerations discussed in the previous section, shows very little sensitivity to countries' unobserved characteristics.

\section{Conclusion}

This paper examines the factors affecting the choice of exchange rate regime in inflation targeting emerging markets. The paper's main findings are: (i) EM IT countries on average have a relatively more flexible exchange rate regime than other EMs, and (ii) the prevailing macroeconomic environment affects the choice of the exchange rate regime. To be more specific, macroeconomic characteristics, such as high import dependency and large share of public and private assets/liabilities denominated in foreign currencies, reduce the degree of exchange rate flexibility in EM IT countries. On the other hand, a more-developed domestic financial system and a credible financial openness policy both contribute to greater flexibility, consistent with the commitment under an IT regime.

These results are robust. They are derived from panel data econometric estimates using limited dependent variable models (such as ordered logit and probit), and impact evaluation techniques, such as matching on propensity scores. Regardless of the technique which is used, the results remain qualitatively and quantitatively similar to the baseline estimates.

These results have important policy implications. First, they show the heterogeneity of behavior among IT countries. The macroeconomic environment is important, and understanding the exchange rate policy choices made by EM IT countries appears to be less 
straightforward than originally thought. Special attention should be paid to shifts in de facto exchange rate policies, especially when the macroeconomic environment changes significantly. This could lead to inconsistencies between the de jure exchange rate regime and the de facto exchange rate policy.

Second, the results also show that inflation targeting arrangements in EMs are not yet mature. This is supported by one of our results which shows that the positive association between inflation targeting and exchange rate flexibility increases in countries that have been more successful in controlling inflation including via IT arrangements, and decreases in inflation targeting countries which have difficulty in controlling inflation. This raises the fundamental question of what can be done to improve the marginal benefits of setting-up an IT regime expost. Which complementary policies can/should be put in place to reduce the trade-off between the conflicting objectives? Our paper shows that policies that promote financial development and financial openness can be beneficial in this respect.

Our findings highlight the importance of the multiplicity of objectives pursued by central banks operating under IT arrangements. These issues pose a crucial question as to whether the control of the exchange rate enhances the effectiveness of inflation targeting (by preserving the financial sector stability and improving inflation performances) or undermines it (by generating conflict of objectives and by reducing the credibility of the IT framework). It can be argued that emerging markets inflation targeters may benefit from attempts to control exchange rate fluctuations, at least during a transition period following the adoption of an IT regime. This view is supported by Garcia et al. (2011) who show that financially vulnerable economies are more likely to benefit from the control of exchange rate because they are more likely to be adversely affected by demand shocks and they are more prone to risk premium shocks. Stone et al. (2009) also stress the important role of exchange rate in emerging markets during the transition period toward a full-fledged targeting regime. Resolving the conflict of competing policy objectives (targeting inflation and safeguarding financial stability) can be attained by expanding the set of policy tools. The inflation objective would remain the domain of monetary policy while financial stability risks in IT countries can be managed with the use of effective macroprudential measures which would limit macro risks stemming from exchange rate fluctuations. 


\section{References}

Abo-Zaid, S. and Tuzemen, D., 2012, "Inflation Targeting: A Three-Decade Perspective," Journal of Policy Modeling, 34, pp. 621-645.

Aghion, P., Bacchetta, P., Rancière, R., and Rogoff, K., 2009, "Exchange Rate Volatility and Productivity Growth: The Role of Financial Development," Journal of Monetary Economics, 56(4), pp. 494-513.

Ai, C. and Norton, E. C., 2003, "Interaction Terms in Logit and Probit Models," Economics Letters, 80, pp. 123-129.

Chinn, M. D. and Ito, H., 2008, “A New Measure of Financial Openness," Journal of Comparative Analysis: Research and Practice, 10(3), pp. 309-322.

Dreher, A., De Haan, J., and Sturm, J. E., 2008, "Does High Inflation Cause Central Bankers to Lose Their Job? Evidence Based on a New Dataset," European Journal of Political Economy, 24, pp. 778-787.

Edwards, S. (1996). The Determinants of the Choice between Fixed and Flexible ExchangeRate Regimes. NBER Working Paper $N^{\circ} 5756$.

Garcia, C. J., Restrepo J. E., Roger S. (2011). How Much Should Inflation Targeters Care about the Exchange Rate. Journal of International Money and Finance, 30, 15901617.

Gonçalves, C. and Salles, J. (2008). Inflation Targeting in Emerging Economies: What Do the Data Say? Journal of Development Economics, 85(1-2), 312-318.

Güçlü, M, 2008, "The Determinants of Exchange Rate Regimes in Emerging Market Economies," International Conference on Emerging Economic Issues in a Globalizing World.

Klein, M. and Shambaugh, J. C., 2010, "Exchange Rate Regimes in the Modern Era," The MIT Press.

Lane, P. R. and Milesi-Ferretti, G. M., 2007, "The External Wealth of Nations Mark II: Revised and Extended Estimates of Foreign Assets and Liabilities, 1970-2004," Journal of International Economics , 73, pp. 223-250.

Lin, S., 2010, "On the International Effect of Inflation Targeting," The Review of Economics and Statistics, 92(1), pp. 195-199 (February).

Lin, S. and Ye H., 2009, "Does Inflation Targeting Make a Difference in Developing Countries?" Journal of Development Economics, 89(1), pp. 118-123.

Markiewicz, A., 2006, "Choice of Exchange Rate Regime in Transition Economies: An Empirical Analysis," Journal of Comprative Economics, pp. 484-498. 
Martin, P., Maryer, T., and Thoeing, M., 2012, "The Geography of Conflicts and Free Trade Agreements," American Economic Journal: Macroeconomics, 4 (4), pp. 1-35.

McKinnon, R., 1963, “Optimum Currency Areas,” American Economic Review, 53, pp. $717-725$.

Méon, P-G. and Rizzo, J-M., 2002, “The Viability of Fixed Exchange Rate Commitments: Does Politics Matter? A Theoretical and Empirical Investigation," Open Economies Review, 13, pp. 111-132.

Minea, A. and Tapsoba, R., 2014, "Does Inflation Targeting Improve Fiscal Discipline?" Journal of International Money and Finance, 40, pp. 185-203.

Mishkin, F. S. and Schmidt-Hebbel, K., 2007, "Does Inflation Targeting Make a Difference?" In: F. S. Mishkin and K. Schmidt-Hebbel (Eds), Monetary Policy under Inflation Targeting, Central bank of Chile, pp. 291-372.

Mundell, R., 1961, “A Theory of Optimal Currency Areas,” Amarican Economic Review, 53, pp. 657-665.

Rizzo, J. M., 1998, “The Determinants of the Choice of an Exchange Rate Regime: A Probit Analysis," Economic Letters, 59, pp. 283-287.

Roger, S., 2009, "Inflation Targeting at 20: Achievements and Challenges," IMF Working Paper No. 09/236.

Rose, A., 2011, "Exchange Rate Regimes in the Modern Era: Fixed, Floating, and Flaky." Journal of Economic Literature, 49(3), pp. 652-72.

Rosenbaum, P. R., 2002, Observational Studies. Springer: New York.

Stone, M., Kisinbay, T., Nordstrom, A., Restrepo, J., Roger, S., and Shimizu, S., 2009, “The Role of the Exchange Rate in Inflation-Targeting Emerging Economies," IMF Occasional Paper No. 267.

Vega, M. and Winkelried, D., 2005, "Inflation Targeting and Inflation Behavior: A Successful Story?” International Journal of Central Banking, 1, pp. 153-175.

von Hagen, J. and Zhou, J., 2005, “The Choice of Exchange Rate Regimes: An Empirical Analysis for Transition Economies," Economics of Transition, 13(4), pp. 679-703.

von Hagen, J. and Zhou, J., 2007, "The Choice of Exchange Rate Regimes in Developing Countries: A Multinomial Panel Analysis," Journal of International Money and Finance, 26, pp. 1071-1094. 
APPENDIX

\begin{tabular}{|ccl|}
\hline \multicolumn{4}{|c|}{ Appendix Table 1. De Facto Exchange Rate Regime Classification } \\
\hline Codes & \multicolumn{1}{c|}{ Regimes } \\
\hline 1 & - & No separate legal tender \\
1 & - & Pre announced peg or currency board arrangement \\
1 & - & Pre announced horizontal band that is narrower than or equal to $+/-2$ percent \\
1 & - & De facto peg \\
2 & - & Pre announced crawling peg \\
2 & - & Pre announced crawling band that is narrower than or equal to $+/-2$ percent \\
2 & - & De factor crawling peg \\
2 & - & De facto crawling band that is narrower than or equal to $+/-2$ percent \\
3 & - & Pre announced crawling band that is wider than or equal to $+/-2$ percent \\
3 & - & De facto crawling band that is narrower than or equal to $+/-5$ percent \\
3 & - & Moving band that is narrower than or equal to $+/-2$ percent $($ i.e., allows for both \\
3 & - & appreciation and depreciation over time) \\
4 & Managed floating \\
5 & - & Freely floating \\
6 & - & Freely falling \\
\hline Source: Course classification from Reinhart and Rogoff. \\
\hline
\end{tabular}

\begin{tabular}{|ccc|}
\hline \multicolumn{3}{|c|}{ Appendix Table 2. Sample } \\
\hline IT countries & non-IT countries \\
\hline Brazil (1999) & Algeria & Saudi Arabia \\
Chile (1999) & Argentina & Tunisia \\
Colombia (1999) & Bulgaria & Ukraine \\
Czech Republic* (1997) & China & Venezuela, RB \\
Hungary (2001) & Ecuador & \\
Indonesia (2005) & Egypt, Arab Rep. \\
Israel* (1997) & Hong Kong SAR, China \\
Korea, Rep. (2001) & India \\
Mexico (2001) & Jordan \\
Peru (2002) & Kenya \\
Philippines (2002) & Kuwait \\
Poland (1998) & Libya \\
Romania (2005) & Malaysia \\
South Africa (2000) & Morocco \\
Thailand (2000) & Nigeria \\
Turkey (2006) & Pakistan \\
\hline Enflation targeting adoption date in parentheses. Czech Rep. and Israel are now considered Advanced \\
Source: Roger (2009).
\end{tabular}




\begin{tabular}{|c|c|c|}
\hline \multicolumn{3}{|c|}{ Appendix Table 3. Data and Sources } \\
\hline Variable & Description & Source \\
\hline ERR & $\begin{array}{l}\text { De facto exchange rate regime } \\
\text { classification }\end{array}$ & Reinhart and Rogoff data \\
\hline Trade openness & $\begin{array}{l}\text { Imports + exports of goods and } \\
\text { services in percent of GDP }\end{array}$ & WDI, World Bank \\
\hline Growth & Growth rate of GDP & WDI, World Bank \\
\hline Economic development & Log of real GDP per capita & WDI, World Bank \\
\hline Financial development & $\begin{array}{l}\text { Domestic credit to private sector } \\
\text { in percent of GDP }\end{array}$ & WDI, World Bank \\
\hline Inflation & $\begin{array}{l}\text { Percentage change in consumer } \\
\text { price index }\end{array}$ & WDI, World Bank \\
\hline Reserves & $\begin{array}{l}\text { Total reserves in months of } \\
\text { imports }\end{array}$ & WDI, World Bank \\
\hline KAOPEN & Index of capital openness & $\begin{array}{l}\text { Chinn and Ito (2008, } \\
\text { updated 2011) }\end{array}$ \\
\hline Politics & Index of political instability & ICRG \\
\hline Fiscal & Change in government total debt & $\begin{array}{l}\text { WEO, International } \\
\text { Monetary Fund }\end{array}$ \\
\hline Net imports & $\begin{array}{l}\text { (Imports - exports of goods and } \\
\text { services) in percent GDP }\end{array}$ & WDI, World Bank \\
\hline External debt & $\begin{array}{l}\text { Total external debt in percent of } \\
\text { GDP }\end{array}$ & $\begin{array}{l}\text { WEO, International } \\
\text { Monetary Fund }\end{array}$ \\
\hline Inverse of CBI & $\begin{array}{l}\text { Five-year central bank governors } \\
\text { turnover rate }\end{array}$ & Dreher et al. (2008) \\
\hline Banks assets / liabilities & $\begin{array}{l}\text { Banking institutions' assets / } \\
\text { liabilities }\end{array}$ & $\begin{array}{l}\text { IFS, International } \\
\text { Monetary Fund }\end{array}$ \\
\hline Financial openness & $\begin{array}{l}\text { De facto index of financial } \\
\text { openness = (external financial } \\
\text { liabilities + assets) in percent of } \\
\text { GDP }\end{array}$ & $\begin{array}{l}\text { Lane and Milesi-Ferretti } \\
\text { (2007, updated 2011) }\end{array}$ \\
\hline
\end{tabular}




\begin{tabular}{|c|c|c|c|c|c|c|c|c|c|c|c|}
\hline \multicolumn{12}{|c|}{ Appendix Table 4. Robustness-Random Effects Ordered Probit Estimates (Controlling for Crisis Dummies) } \\
\hline & (1) & (2) & (3) & (4) & (5) & (6) & (7) & (8) & (9) & (10) & (11) \\
\hline IT & $\begin{array}{c}1.380^{* * *} \\
(7.513)\end{array}$ & $\begin{array}{c}1.384 * * * \\
(7.549)\end{array}$ & $\begin{array}{c}1.556^{* * *} \\
(7.260)\end{array}$ & $\begin{array}{c}1.298^{* * *} \\
(6.951)\end{array}$ & $\begin{array}{c}0.695^{* *} \\
(2.419)\end{array}$ & $\begin{array}{c}0.449 \\
(1.382)\end{array}$ & $\begin{array}{c}0.438 \\
(1.458)\end{array}$ & $\begin{array}{c}1.486 * * * \\
(7.176)\end{array}$ & $\begin{array}{c}1.230 * * * \\
(6.084)\end{array}$ & $\begin{array}{c}1.414 * * * \\
(6.841)\end{array}$ & $\begin{array}{c}0.375 \\
(1.514)\end{array}$ \\
\hline IT*Trade openness & & $\begin{array}{c}0.0142 * * * \\
(2.941)\end{array}$ & & & & & & & & & \\
\hline IT* Financial openness & & & $\begin{array}{c}0.0198 * * * \\
(3.889)\end{array}$ & & & & & & & & \\
\hline IT* Financial development & & & & $\begin{array}{c}0.0183 * * * \\
(3.820)\end{array}$ & & & & & & & \\
\hline IT*Banks foreign assets/total assets & & & & & $\begin{array}{c}-0.0334 * * \\
(-2.157)\end{array}$ & & & & & & \\
\hline IT*Banks foreign liabilities/total assets & & & & & & $\begin{array}{c}-0.00877 * * * \\
(-2.690)\end{array}$ & & & & & \\
\hline IT*Inflation & & & & & & & $\begin{array}{c}-0.142 * * * \\
(-3.894)\end{array}$ & & & & \\
\hline IT* Net imports & & & & & & & & $\begin{array}{c}-0.0984 * * * \\
(-4.816)\end{array}$ & & & \\
\hline IT*External debt & & & & & & & & & $\begin{array}{c}-0.0193 * * * \\
(-2.641)\end{array}$ & & \\
\hline IT*Pscore & & & & & & & & & & $\begin{array}{c}2.226^{* *} \\
(2.415)\end{array}$ & \\
\hline IT*Time & & & & & & & & & & & $\begin{array}{c}0.223 * * * \\
(5.828)\end{array}$ \\
\hline Controls and additive terms included? & yes & yes & yes & yes & ye & yes & yes & yes & yes & yes & Yes \\
\hline Observations & 640 & 640 & 642 & 640 & 594 & 594 & 640 & 588 & 624 & 602 & 640 \\
\hline Number of id & 36 & 36 & 36 & 36 & 35 & 35 & 36 & 36 & 36 & 35 & 36 \\
\hline Wald chi2 stat & 90.83 & 98.79 & 92.60 & 100.3 & 81.27 & 82.20 & 102.8 & 121.1 & 96.47 & 92.00 & 115.6 \\
\hline \multicolumn{12}{|c|}{$\begin{array}{l}\text { Random effects probit model with panel data; constant included but not reported; the control variables as well as additive terms forming the interaction variables (not reported) are the same as in Table } 1 \text {, in } \\
\text { addition to Banking crisis, Currency crisis, and Sovereign debt crisis dummies; all the controls (except IT) are included with } 1 \text { year lag; the Wald chi2 test is a test for the null hypothesis that all the coefficients } \\
\text { except the constant, are jointly equal to zero; } * * *, * *, * \text { indicate the statistical significance at } 1,5 \text {, and } 10 \text { percent respectively. }\end{array}$} \\
\hline Source: & & & & & & & & & & & \\
\hline
\end{tabular}




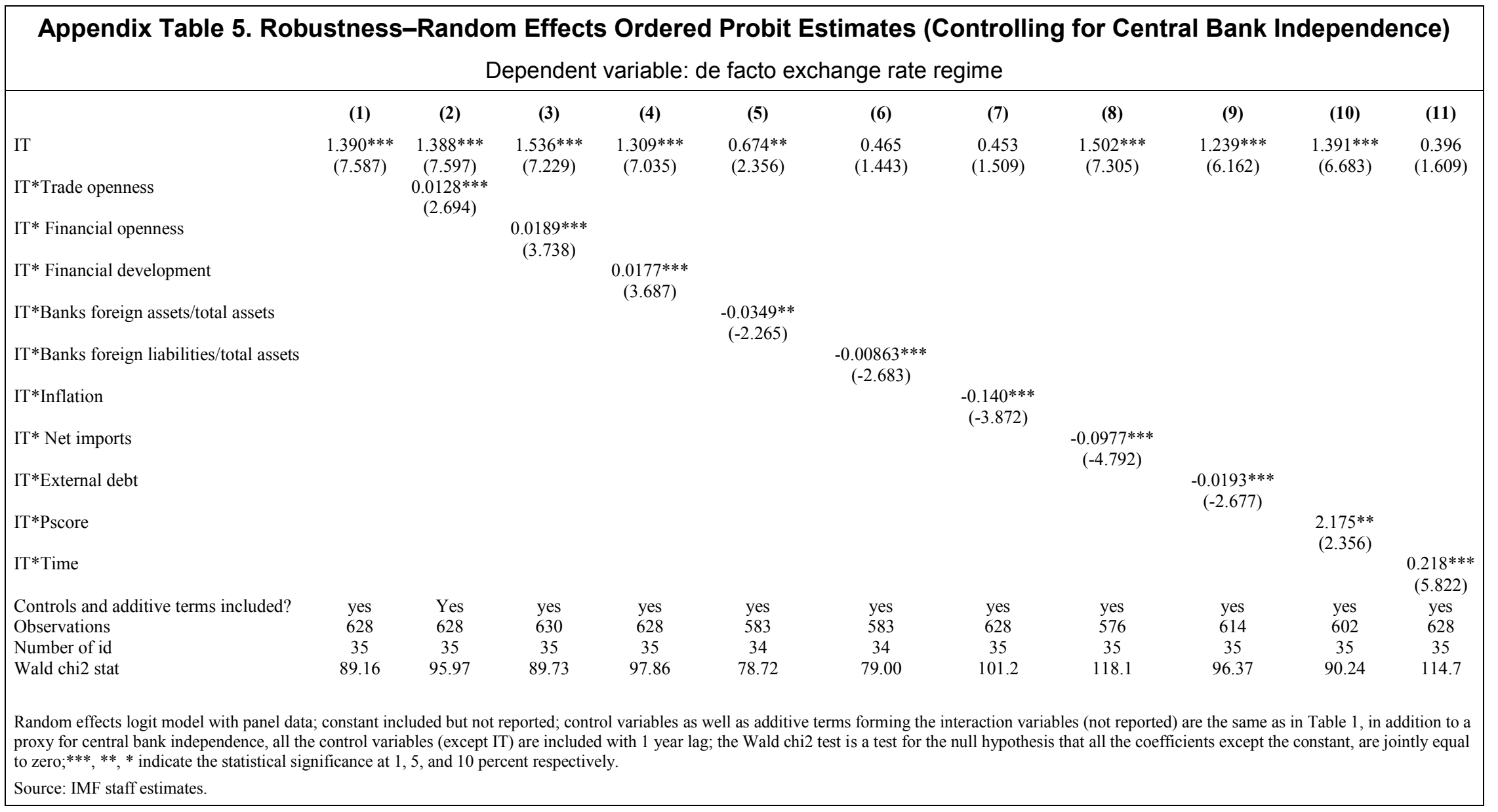




\begin{tabular}{|c|c|c|c|c|c|c|c|c|c|c|c|}
\hline \multicolumn{12}{|c|}{ Appendix Table 6. Robustness-Linear Probability Model } \\
\hline \multicolumn{12}{|c|}{ Dependent variable: de facto exchange rate regime } \\
\hline & (1) & (2) & (3) & (4) & (5) & (6) & (7) & (8) & (9) & (10) & (11) \\
\hline IT & $\begin{array}{c}0.504 * * * \\
(6.105)\end{array}$ & $\begin{array}{c}0.529 * * * \\
(6.419)\end{array}$ & $\begin{array}{c}0.468 * * * \\
(5.754)\end{array}$ & $\begin{array}{c}0.457 * * * \\
(5.464)\end{array}$ & $\begin{array}{l}0.262 * \\
(1.931)\end{array}$ & $\begin{array}{c}0.160 \\
(1.043)\end{array}$ & $\begin{array}{l}0.0940 \\
(0.726)\end{array}$ & $\begin{array}{c}0.494 * * * \\
(6.069)\end{array}$ & $\begin{array}{c}0.378 * * * \\
(4.591)\end{array}$ & $\begin{array}{c}0.489^{* * * *} \\
(5.208)\end{array}$ & $\begin{array}{c}0.148 \\
(1.402)\end{array}$ \\
\hline IT*Trade openness & & $\begin{array}{c}0.00689 * * * \\
(3.115)\end{array}$ & & & & & & & & & \\
\hline IT* Financial openness & & & $\begin{array}{c}0.00251 * * \\
(2.032)\end{array}$ & & & & & & & & \\
\hline IT* Financial development & & & & $\begin{array}{c}0.00546^{* * * *} \\
(2.981)\end{array}$ & & & & & & & \\
\hline IT*Banks foreign assets/total assets & & & & & $\begin{array}{c}-0.0124 * \\
(-1.782)\end{array}$ & & & & & & \\
\hline IT*Banks foreign liabilities/total assets & & & & & & $\begin{array}{c}-0.00336 * * \\
(-2.259)\end{array}$ & & & & & \\
\hline IT*Inflation & & & & & & & $\begin{array}{c}-0.0619 * * * \\
(-4.079)\end{array}$ & & & & \\
\hline IT* Net imports & & & & & & & & $\begin{array}{c}-0.0361 * * * \\
(-4.515)\end{array}$ & & & \\
\hline IT*External debt & & & & & & & & & $\begin{array}{c}-0.00861 * * * \\
(-2.956)\end{array}$ & & \\
\hline IT*Pscore & & & & & & & & & & $\begin{array}{c}0.984 * * \\
(2.335)\end{array}$ & \\
\hline IT*Time & & & & & & & & & & & $\begin{array}{c}0.0764 * * * \\
(5.221)\end{array}$ \\
\hline Constant & $\begin{array}{c}0.860 \\
(0.727)\end{array}$ & $\begin{array}{c}0.761 \\
(0.648)\end{array}$ & $\begin{array}{c}1.007 \\
(0.849)\end{array}$ & $\begin{array}{c}0.601 \\
(0.510)\end{array}$ & $\begin{array}{c}2.010 \\
(1.532)\end{array}$ & $\begin{array}{l}2.193 * \\
(1.672)\end{array}$ & $\begin{array}{c}0.954 \\
(0.817)\end{array}$ & $\begin{array}{l}1.973^{*} \\
(1.728)\end{array}$ & $\begin{array}{c}-0.732 \\
(-0.612)\end{array}$ & $\begin{array}{c}-0.921 \\
(-0.725)\end{array}$ & $\begin{array}{c}1.711 \\
(1.464)\end{array}$ \\
\hline Controls and additive terms included? & yes & Yes & yes & yes & yes & yes & Yes & yes & yes & yes & yes \\
\hline Observations & 640 & 640 & 642 & 640 & 594 & 594 & 640 & 588 & 624 & 602 & 640 \\
\hline R-squared & 0.118 & 0.133 & 0.115 & 0.131 & 0.110 & 0.112 & 0.142 & 0.208 & 0.173 & 0.129 & 0.157 \\
\hline Number of id & 36 & 36 & 36 & 36 & 35 & 35 & 36 & 36 & 36 & 35 & 36 \\
\hline F stat & 7.976 & 8.239 & 7.019 & 8.155 & 6.179 & 6.274 & 8.954 & 12.91 & 10.01 & 6.854 & 10.05 \\
\hline
\end{tabular}




\begin{tabular}{|c|c|c|c|c|c|c|c|c|c|c|c|c|c|c|c|c|c|}
\hline \multicolumn{18}{|c|}{ Appendix Table 7. Probit Model of the Matching Estimates } \\
\hline & & \multicolumn{2}{|c|}{ External debt } & \multicolumn{2}{|c|}{$\begin{array}{c}\text { Banks foreign assets/total } \\
\text { assets }\end{array}$} & \multicolumn{2}{|c|}{$\begin{array}{c}\text { Banks foreign } \\
\text { liabilities/total assets } \\
\end{array}$} & \multicolumn{2}{|c|}{ Inflation } & \multicolumn{2}{|c|}{ Net imports } & \multicolumn{2}{|c|}{ Financial openness } & \multicolumn{2}{|c|}{ Trade openness } & \multicolumn{2}{|c|}{ Financial development } \\
\hline & Baseline & Low & High & Low & High & Low & High & Low & High & Low & High & Low & High & Low & High & Low & High \\
\hline \multirow[t]{2}{*}{ Trade openness } & $-0.0065^{* * *}$ & $-0.0095 * * *$ & -0.0021 & $-0.0153^{* * *}$ & $-0.00307^{*}$ & $-0.0122 * * *$ & $-0.0033^{* *}$ & $-0.0056^{* * *}$ & $-0.0066^{* * *}$ & $-0.0069^{* * *}$ & $-0.0057^{* * *}$ & $-0.0091^{* * *}$ & $-0.006^{* * *}$ & $-0.0384 * * *$ & -0.0012 & -0.0014 & $-0.0087^{* * *}$ \\
\hline & $(-4.172)$ & $(-4.455)$ & $(-1.118)$ & $(-4.501)$ & $(-1.942)$ & $(-4.300)$ & $(-2.022)$ & $(-2.902)$ & $(-3.523)$ & $(-3.640)$ & $(-2.898)$ & $(-2.958)$ & $(-3.640)$ & $(-6.600)$ & $(-0.756)$ & $(-0.470)$ & $(-4.881)$ \\
\hline \multirow[t]{2}{*}{ Growth } & $-0.0385 * *$ & -0.0292 & $-0.0401 *$ & -0.0108 & $-0.0569 * * *$ & -0.0242 & $-0.0461 * *$ & -0.0188 & $-0.0456 * *$ & $-0.0494 * *$ & -0.0222 & -0.0199 & $-0.0454 *$ & $-0.0477 *$ & -0.0214 & 0.00566 & $-0.0666 * * *$ \\
\hline & $(-2.034)$ & $(-1.251)$ & $(-1.819)$ & $(-0.448)$ & $(-2.595)$ & $(-0.977)$ & $(-2.188)$ & $(-0.763)$ & $(-2.174)$ & $(-2.193)$ & $(-0.980)$ & $(-0.888)$ & $(-1.902)$ & $(-1.920)$ & $(-0.903)$ & $(0.244)$ & $(-2.618)$ \\
\hline \multirow[t]{2}{*}{ Economic dev. } & $0.479 * * *$ & $0.401^{* * *}$ & $0.476^{* * *}$ & $0.412^{* * *}$ & $0.453^{* * *}$ & $0.365^{* * *}$ & $0.485^{* * *}$ & $0.457^{* * *}$ & $0.414 * * *$ & $0.360^{* * *}$ & $0.497^{* * *}$ & $0.375^{* * *}$ & $0.608^{* * *}$ & $0.576^{* * *}$ & $0.438^{* * *}$ & $0.397^{* * *}$ & $0.663 * * *$ \\
\hline & $(7.463)$ & $(4.936)$ & (6.335) & $(5.100)$ & $(6.006)$ & $(4.530)$ & $(6.470)$ & $(5.356)$ & $(5.702)$ & $(4.666)$ & $(6.327)$ & $(5.161)$ & $(6.293)$ & $(5.944)$ & $(5.600)$ & (5.111) & $(6.127)$ \\
\hline \multirow[t]{2}{*}{ Financial dev. } & 0.00203 & $0.00840^{* * *}$ & $-0.00662^{* *}$ & 0.00423 & 0.00261 & $0.00678^{* * *}$ & -0.000260 & $0.00555^{* *}$ & 0.000769 & $0.00809^{* * *}$ & -0.00218 & $-0.00661^{* *}$ & $0.0107^{* * *}$ & 0.00398 & 0.00280 & $-0.0351 * * *$ & $0.0191 * * *$ \\
\hline & $(1.033)$ & (3.714) & $(-2.120)$ & $(1.564)$ & $(1.143)$ & (2.614) & $(-0.109)$ & (2.134) & $(0.329)$ & (3.284) & $(-0.873)$ & $(-2.156)$ & $(4.426)$ & $(1.532)$ & $(1.112)$ & $(-5.683)$ & $(6.805)$ \\
\hline \multirow[t]{2}{*}{ Inflation, lagged } & $-0.0597^{* * *}$ & $-0.0521^{* * *}$ & $-0.0540^{* * *}$ & $-0.0586^{* * *}$ & $-0.0496^{* * *}$ & $-0.0618^{* * *}$ & $-0.047^{* * *}$ & $-0.0863^{* * *}$ & $-0.0423^{* * *}$ & $-0.0580^{* * *}$ & $-0.0484^{* * *}$ & $-0.0487^{* * *}$ & $-0.0743^{* * *}$ & $-0.0509^{* * *}$ & $-0.0721^{* * *}$ & $-0.0597^{* * *}$ & $-0.0709 * * *$ \\
\hline & $(-5.130)$ & $(-3.358)$ & $(-4.256)$ & $(-3.921)$ & $(-3.628)$ & $(-3.811)$ & $(-3.791)$ & $(-4.026)$ & $(-3.828)$ & $(-3.679)$ & $(-3.870)$ & $(-4.244)$ & $(-3.579)$ & $(-3.960)$ & $(-3.881)$ & $(-5.160)$ & $(-3.024)$ \\
\hline \multirow[t]{2}{*}{ Reserves } & $-0.0377 * *$ & -0.0294 & $-0.0369^{*}$ & -0.0179 & $-0.0538^{* * *}$ & -0.0303 & $-0.0364 *$ & -0.0164 & $-0.0525^{* *}$ & -0.0137 & $-0.0596 * *$ & -0.0271 & $-0.0430 *$ & -0.0178 & $-0.0623 * *$ & $-0.0500 * * *$ & -0.0308 \\
\hline & $(-2.295)$ & $(-1.478)$ & $(-1.907)$ & $(-0.983)$ & $(-2.296)$ & $(-1.503)$ & $(-1.857)$ & $(-0.844)$ & $(-2.461)$ & $(-0.767)$ & $(-2.454)$ & $(-1.528)$ & $(-1.778)$ & $(-0.902)$ & $(-2.302)$ & $(-2.609)$ & $(-1.180)$ \\
\hline \multirow[t]{2}{*}{ Fiscal deficit } & 0.00121 & -0.00232 & 0.00318 & 0.000295 & -0.00161 & -0.00653 & 0.00397 & 0.00438 & -0.00194 & -0.0117 & 0.0101 & 0.00381 & -0.000673 & -0.0131 & 0.00362 & 0.00501 & -0.00219 \\
\hline & $(0.148)$ & $(-0.207)$ & $(0.367)$ & $(0.0283)$ & $(-0.170)$ & $(-0.572)$ & $(0.447)$ & $(0.440)$ & $(-0.213)$ & $(-1.059)$ & $(1.120)$ & $(0.431)$ & $(-0.0624)$ & $(-1.037)$ & $(0.374)$ & $(0.602)$ & $(-0.175)$ \\
\hline \multirow[t]{2}{*}{ Inverse of CBI } & $-0.907 * *$ & $-1.268^{* *}$ & -0.472 & $-0.939 * *$ & -0.738 & $-0.901 *$ & -0.743 & -0.217 & $-1.159 * * *$ & -0.417 & $-1.183^{* *}$ & $-1.115^{* *}$ & -0.405 & $-1.595 * * *$ & -0.344 & $-0.980^{* *}$ & -0.619 \\
\hline & $(-2.339)$ & $(-2.426)$ & $(-1.085)$ & $(-2.030)$ & $(-1.549)$ & $(-1.867)$ & $(-1.640)$ & $(-0.422)$ & $(-2.655)$ & $(-0.891)$ & $(-2.499)$ & $(-2.527)$ & $(-0.752)$ & $(-3.262)$ & $(-0.682)$ & $(-2.221)$ & $(-1.014)$ \\
\hline \multirow[t]{2}{*}{ Constant } & $-3.387^{* * *}$ & $-3.392 * * *$ & $-3.735^{* * *}$ & $-3.045^{* * *}$ & $-3.782 * * *$ & $-2.851^{* * *}$ & $-3.992 * * *$ & $-4.223 * * *$ & $-3.016^{* * *}$ & $-3.323^{* * *}$ & $-3.738^{* * *}$ & $-2.466^{* * *}$ & $-5.542 * * *$ & $-2.918^{* * *}$ & $-3.949^{* * *}$ & $-2.080^{* * *}$ & $-6.464 * * *$ \\
\hline & $(-5.936)$ & $(-4.612)$ & $(-5.662)$ & $(-4.269)$ & $(-5.527)$ & $(-3.910)$ & $(-5.979)$ & $(-5.304)$ & $(-4.732)$ & $(-4.747)$ & $(-5.378)$ & $(-3.917)$ & $(-6.036)$ & $(-3.810)$ & $(-5.410)$ & $(-3.173)$ & $(-6.118)$ \\
\hline Observations & 691 & 618 & 624 & 614 & 628 & 613 & 629 & 607 & 635 & 619 & 623 & 623 & 619 & 621 & 621 & 624 & 618 \\
\hline Pseudo R2 & 0.240 & 0.242 & 0.224 & 0.225 & 0.243 & 0.219 & 0.233 & 0.267 & 0.201 & 0.226 & 0.231 & 0.195 & 0.336 & 0.325 & 0.266 & 0.281 & 0.432 \\
\hline
\end{tabular}

CInternational Monetary Fund. Not for Redistribution 